ANL/D\&D/01-1

\title{
Decontamination and Decommissioning of the 60" Cyclotron Facility at Argonne National Laboratory-East Project Final Report
}

\section{Decontamination and Decommissioning Program}

Argonne National Laboratory

9700 South Cass Avenue

Argonne, Illinois 60439
Operated by The University of Chicago, under Contract W-31-109-ENG-38, for the United States Department of Energy 
Argonne National Laboratory

Argonne National Laboratory, with facilities in the states of Illinois and Idaho, is owned by the United States Government, and operated by The University of Chicago under the provisions of a contract with the Department of Energy.

This final project report is a product of Argonne's Technology Development Division, Decontamination and Decommissioning Program. For information on the division's activities, contact:

Director, Technology Development Division

Argonne National Laboratory

Argonne, Illinois 60439-4841

Telephone (630) 252-3293

\section{Disclaimer}

This report was prepared as an account of work sponsored by an agency of the United States Government. Neither the United States Government nor any agency thereof, nor The University of Chicago, nor any of their employees or officers, makes any warranty, express or implied, or assumes any legal liability or responsibility for the accuracy, completeness, or usefulness of any information, apparatus, product, or process disclosed, or represents that its use would not infringe privately owned rights. Reference herein to any specific commercial product, process, or service by trade name, trademark, manufacturer, or otherwise, does not necessarily constitute or imply its endorsement, recommendation, or favoring by the United States Government or any agency thereof. The views and opinions of document authors expressed herein do not necessarily state or reflect those of the United States Government or any agency thereof, Argonne National Laboratory, or The University of Chicago.

Available electronically at http://www.gov/bridge

Available for a processing fee to U.S. Department of Energy and its contractors, in paper, from:

U. S. Department of Energy

Office of Scientific and Technical Information

P.O. Box 62

Oak Ridge, TN 37831-0062

phone: (865) 576-8401

fax: (865) 576-5728

email: reports@adonis.osti.gov 
Decontamination and Decommissioning of the 60" Cyclotron Facility

at Argonne National Laboratory-East

Project Final Report

\author{
Edward L. Collins \\ Julien Boyance \\ Frances R. Clark \\ D. John Tinnin \\ Andre Williams
}

Decontamination and Decommissioning Program

Technology Development Division

Argonne National Laboratory

9700 South Cass Avenue

Argonne, Illinois 60439

February 2001

Work sponsored by United States Department of Energy, Office of Environmental Management 
60" Cyclotron Facility D\&D Project

Final Report

Page ii of $x$

Page Left Blank 


\section{TABLE OF CONTENTS}

$\underline{\text { Page }}$

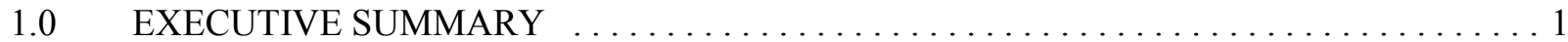

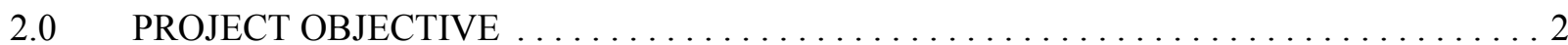

$3.0 \quad$ FACILITY DESCRIPTION AND HISTORY $\ldots \ldots \ldots \ldots \ldots \ldots \ldots \ldots \ldots \ldots$

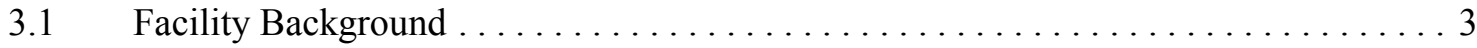

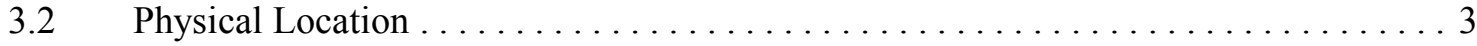

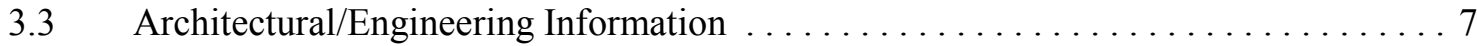

3.3.1 General Statement . . . . . . . . . . . . . . . . . . . . . . 7

3.3.2 Description of the 60" Cyclotron and Supporting Features . . . . . . . . . . 7

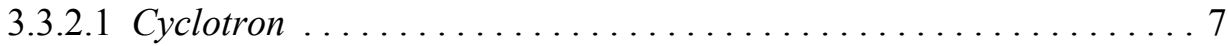

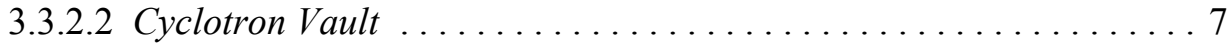

3.3.2.3 Hot Lab $(B-118-B-126) \ldots \ldots \ldots \ldots \ldots \ldots \ldots \ldots$

3.3.2.4 Basement ............................8

3.3.3 Cyclotron Conditions after Deactivation $\ldots \ldots \ldots \ldots \ldots \ldots \ldots$

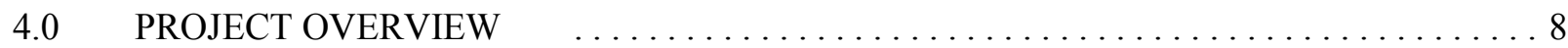

$5.0 \quad$ PROJECT PLANNING AND ENGINEERING $\ldots \ldots \ldots \ldots \ldots \ldots \ldots \ldots \ldots \ldots$

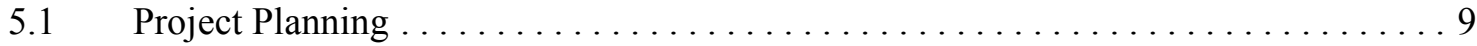

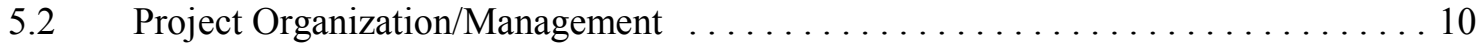

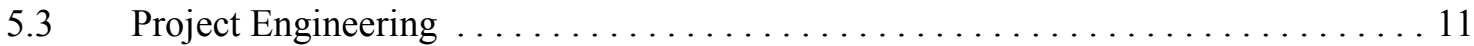

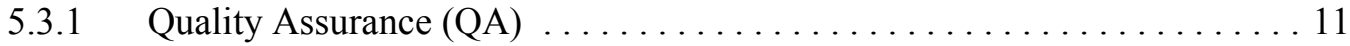

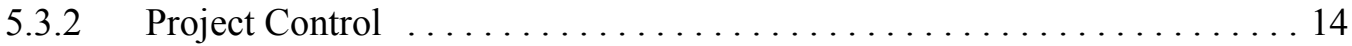

$5.3 .3 \quad$ Project Data . . . . . . . . . . . . . . . . . . . . . . . . 14

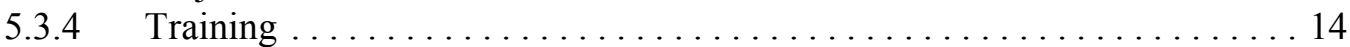

$5.3 .5 \quad$ Health Physics ............................... 15

5.3.6 Health and Safety . . . . . . . . . . . . . . . . . . . . . 15

5.3.6.1 Environment, Safety, and Health Policy . . . . . . . . . . . 15

5.3.6.2 Radiation Safety ........................ 16

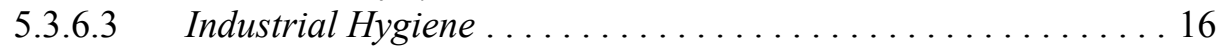

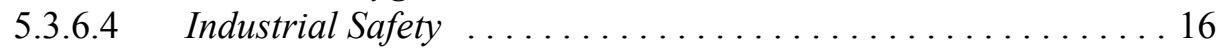

5.3.6.5 Fire Protection and Security .................. 16

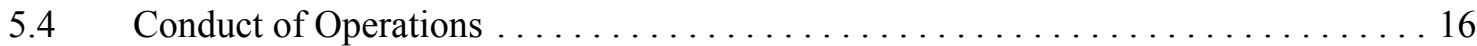

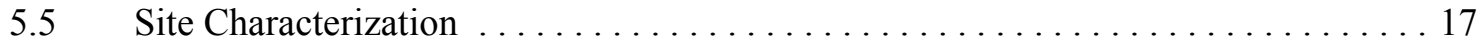


6.0 DECOMMISSIONING OPERATIONS $\ldots \ldots \ldots \ldots \ldots \ldots \ldots \ldots \ldots \ldots \ldots \ldots \ldots$

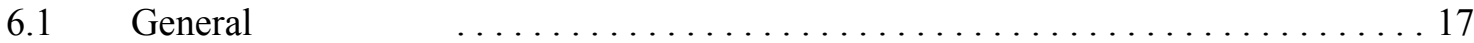

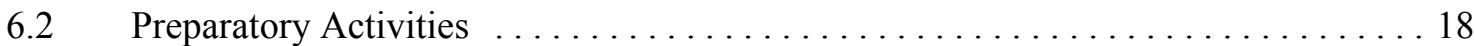

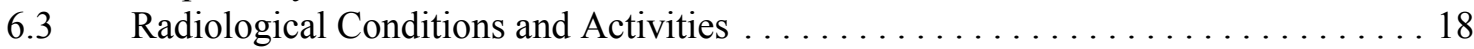

6.3.1 Instrumentation and Equipment $\ldots \ldots \ldots \ldots \ldots \ldots \ldots \ldots \ldots \ldots \ldots \ldots$

6.3.2 Radiological Conditions ............................. 19

6.3.2.1 Dose Rates . . . . . . . . . . . . . . . . . . . . . . . . . . . 19

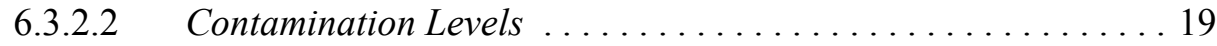

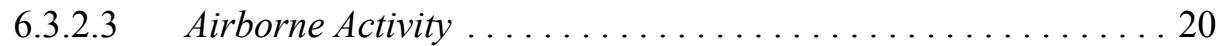

6.3.3 Radiological Incidents . . . . . . . . . . . . . . . . . . . 20

6.3.3.1 Removal of Activated Aluminum Off-Site . . . . . . . . . . . 20

6.3.3.2 Release of Activated I-Beam for Recycling . . . . . . . . . . 20

6.3.3.3 Unplanned Release of Radon Gas ................... 21

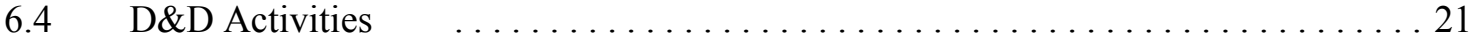

$6.4 .1 \quad$ Initial Activities . . . . . . . . . . . . . . . . . . . . 21

6.4.2 Disassembly and Size Reduction of Cyclotron Support Components . . . . 21

6.4.3 Cyclotron Dismantlement ........................... 23

6.4.4 Hot Lab D\&D ... . . . . . . . . . . . . . . . . . . . . . . . 25

6.4.4.1 Junior Cave .......................... 25

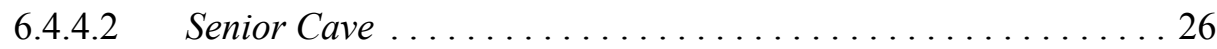

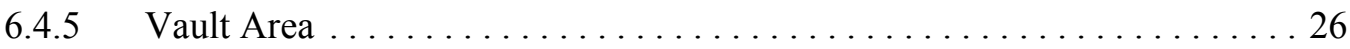

6.4.6 Support Areas . . . . . . . . . . . . . . . . . . . . 27

6.4.7 Facility Asbestos Removal and Ceiling Tile Removal . . . . . . . . . 27

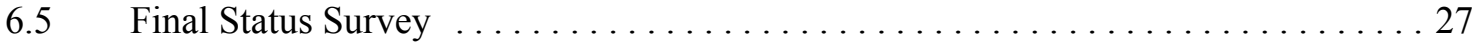

6.5.1 Decontaminate and Wipe Down Surfaces ................. 27

6.5.2 Perform Final Status Survey . . . . . . . . . . . . . . . . . 27

6.5.2.1 Final Survey Objectives $\ldots \ldots \ldots \ldots \ldots \ldots \ldots \ldots \ldots \ldots$

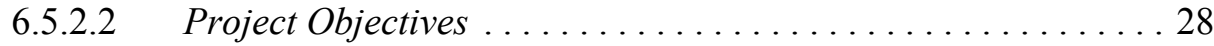

6.5.2.3 Unrestricted Release Criteria ................. 28

6.5.2.4 Final Survey Approach ........................ 30

6.5.2.5 Potential Contaminants ....................... 31

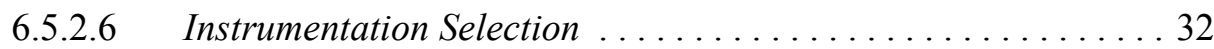

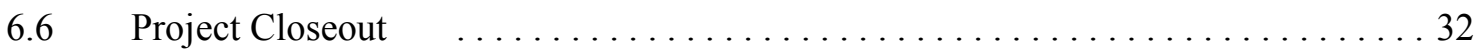

$7.0 \quad$ INDEPENDENT VERIFICATION SURVEY (IVS) $\ldots \ldots \ldots \ldots \ldots \ldots \ldots \ldots \ldots \ldots \ldots$

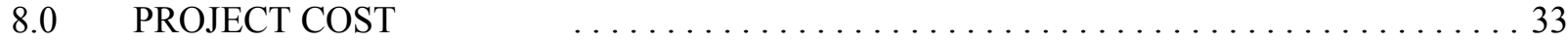

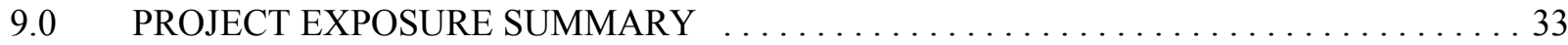

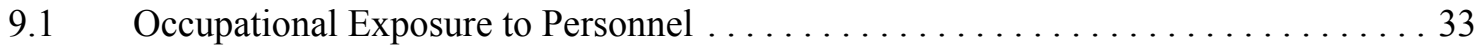

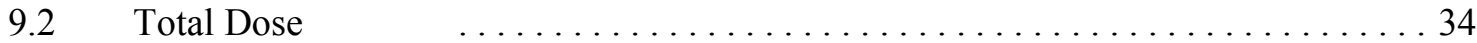




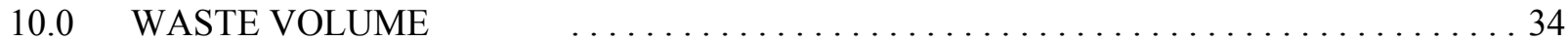

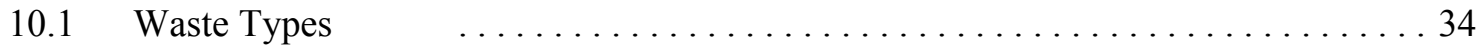

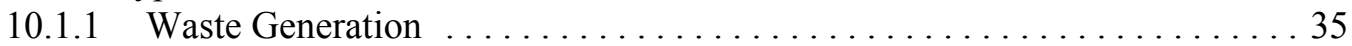

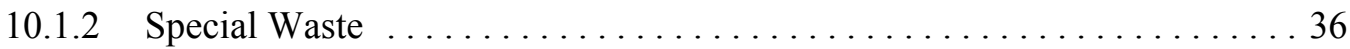

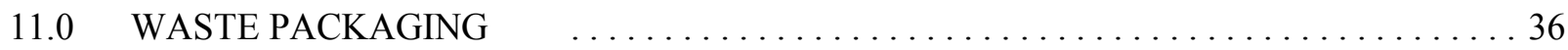

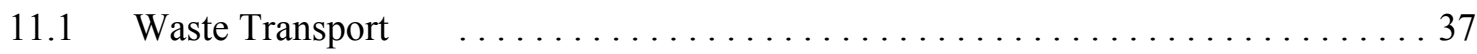

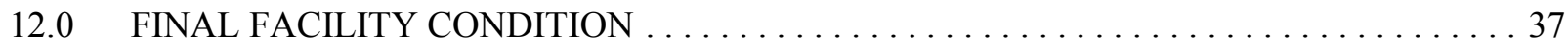

13.0 CONCLUSIONS, RECOMMENDATIONS, AND LESSONS LEARNED . . . . . . . . 38

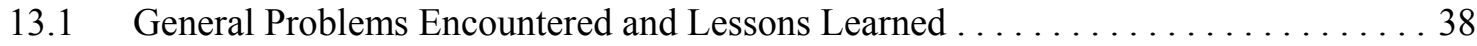

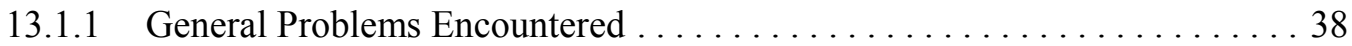

13.1.2 Problem Remediation/Resolution . . . . . . . . . . . . . . . . . . 38

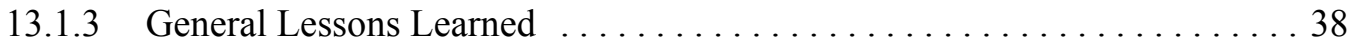

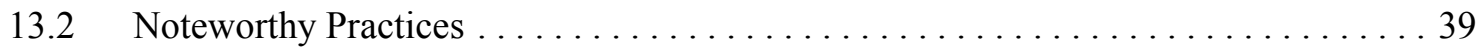

14.0 ACRONYM AND ABBREVIATION LISTING $\ldots \ldots \ldots \ldots \ldots \ldots \ldots \ldots \ldots \ldots \ldots \ldots$ 
60" Cyclotron Facility D\&D Project

Final Report

Page vi of $x$

Page Left Blank 


\section{LIST OF TABLES}

\section{$\underline{\text { Page }}$}

Table $6.1 \quad$ Contractor Instrumentation Used During D\&D . . . . . . . . . . . . . . . . . . 19

Table 6.2 Cyclotron Radiological Contaminants and Activation Products . . . . . . . . . . . . . 29

Table 6.3 Cyclotron Survey Area Classifications and Descriptions List . . . . . . . . . . . 31

Table 6.4 Instrumentation and Nominal Measurement Detection Sensitivities . . . . . . . . 32

Table $9.1 \quad$ Project Total Radiation Dose Equivalent $\ldots \ldots \ldots \ldots \ldots \ldots \ldots \ldots \ldots \ldots \ldots$

Table 10.1 Low Level Radioactive and Mixed Waste Packaged $\ldots \ldots \ldots \ldots \ldots \ldots \ldots \ldots \ldots$ 
60" Cyclotron Facility D\&D Project

Final Report

Page viii of $\mathrm{x}$

Page Left Blank 


\section{LIST OF FIGURES}

Figure $3.1 \quad$ Building 211 Cyclotron Facility, Service Floor $\ldots \ldots \ldots \ldots \ldots \ldots \ldots \ldots \ldots \ldots$

Figure 3.2 Building 211 Cyclotron Facility, Main Floor $\ldots \ldots \ldots \ldots \ldots \ldots \ldots \ldots \ldots \ldots \ldots$

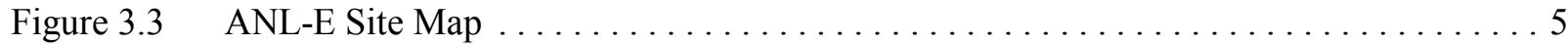

Figure $5.1 \quad$ Relationship between DOE, ANL-E and Subcontractors $\ldots \ldots \ldots \ldots \ldots \ldots \ldots \ldots 12$

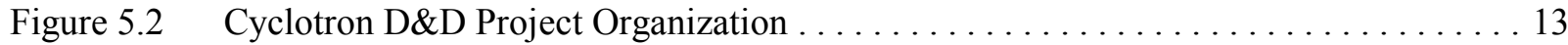

Figure $6.1 \quad$ Disassembly and Removal of High-Voltage Transformer . . . . . . . . . . . . . . 22

Figure 6.2 Cyclotron Piping was Disassembled and Size Reduced . . . . . . . . . . . . . . . . . 22

Figure 6.3 Once the Upper Magnet Coil was Lowered, the Outer Skin Was Removed . . . . . . 23

Figure 6.4 First the Saw Is Set In Place Over the Upper Yoke . . . . . . . . . . . . . . . . . 24

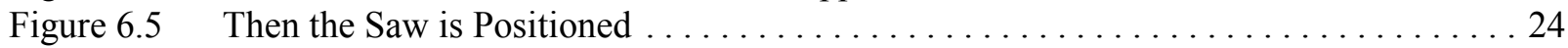

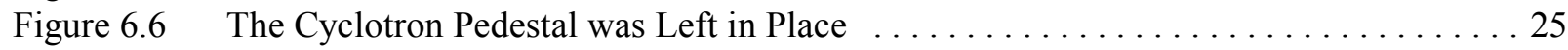

Figure 6.7 Cyclotron Facility Service Floor after Completion of D\&D Activities ........... 26 
60" Cyclotron Facility D\&D Project

Final Report

Page $x$ of $x$

Page Left Blank 


\subsection{EXECUTIVE SUMMARY}

This final report of the decontamination and decommissioning (D\&D) of the Argonne National Laboratory-East (ANL-E) 60" Cyclotron Accelerator Facility contains descriptions and evaluations of activities performed, and results obtained in connection with the Cyclotron D\&D Project. It provides the following information:

- Objective of the Cyclotron D\&D Project

- A brief history of the Cyclotron facility

- Overall descriptions of the Cyclotron facility and the ANL-E site

- An overview of the D\&D activities performed in connection with the Cyclotron D\&D Project

- Summary of the final status of the Cyclotron facility, including results of the final and confirmation surveys.

- $\quad$ Final cost and schedule for the Cyclotron D\&D Project

- Summaries of personnel exposure and total waste generated in connection with this project.

- Final facility condition

This project final report was written in accordance with the requirements of the ANL-E D\&D Project Planning Guidance Manual and the ANL-E D\&D Program Management Plan. It covers the entire Cyclotron D\&D Project, from the initiation of D\&D activities to final project closeout. At the conclusion of the Independent Verification Survey (IVS), the Cyclotron facility was released for unrestricted reuse. Residual, elevated activity remains in inaccessible areas, however. The upper floor of the Cyclotron vault contains readily measurable radioactivity from neutron activation of the concrete and other structures resulting from Cyclotron operations. In accessible areas, the exposure rate criteria in DOE Order 5400.5, i.e., $\leq 20 \mu \mathrm{R} / \mathrm{hr}$, was met. No Radiation Work Permits (RWPs), radiation monitors, or other radiological controls are needed to enter the area. There is no planned use for the former Cyclotron vault and hot lab areas at this time. The issuance of this report signifies the conclusion of the Cyclotron D\&D Project and the transfer of the Cyclotron facility from the U.S. Department of Energy (DOE) Environmental Management roster to the landlord.

MOTA Corporation and their subcontractor, Duke Engineering \& Services, performed the final survey. ANL-E and the Oak Ridge Institute for Science and Education (ORISE) performed the IVS. 
MOTA's Final Status Survey documentation includes fourteen portfolios, each consisting of a Survey Package Control Form, General Instructions Form, Data Results from Smears, Survey Maps, and Survey Data Results. MOTA provided a detailed description of the methodology that was utilized in the Final Status Survey and a summary of the results in their Final Project Report.

ANL-E Health Physics (HP) provided health physics oversight, which included verification of MOTA's Final Status Survey results, by surveying at least $10 \%$ of the survey units.

All project records and documents, including the MOTA documents mentioned above, were archived at the completion of the project.

Characterization, planning, and documentation began in June 1997, completing in December 1998. D\&D field work began in January 2000, and the final report was issued in February 2001. Total duration of D\&D field work was 13 months. The total exposure to project personnel was 0.436 person-rem. The total cost of the Cyclotron D\&D Project, including labor, management, and waste disposal, was $\$ 3.9$ million. A total of $6,971 \mathrm{ft}^{3}$ of low level radioactive waste (LLAW), with a total activity of $5.1 \times 10^{-2} \mathrm{Ci}$ was packaged for off-site disposal. Additionally, $115 \mathrm{ft}^{3}$ of mixed waste, including liners, was packaged for disposal with a total activity of $2.9 \times 10^{-5} \mathrm{Ci}$. In February 2001, the Cyclotron facility was formally decommissioned and transferred to the landlord.

\subsection{PROJECT OBJECTIVE}

The Cyclotron D\&D Project was directed toward the following objectives:

- Elimination of safety concerns associated with facility radiation and contamination levels.

- Removal of radioactive materials associated with the Cyclotron facility from the ANL-E site.

- Decontamination of the Cyclotron facility to unrestricted reuse levels.

- Cleanup of the facility and its formal decommissioning.

- $\quad$ Reuse of the facility for other purposes.

Prior to initiation of the Cyclotron D\&D Project, the primary area of concern associated with the facility was removal of material activated by operations. A secondary concern was the decontamination and removal of hazardous materials from the senior cave and hot lab areas.

The primary radionuclide of concern, for activation, was ${ }^{60} \mathrm{Co}$, with smaller quantities of ${ }^{54} \mathrm{Mn},{ }^{55} \mathrm{Fe}$, ${ }^{63} \mathrm{Ni}$, and trace quantities of miscellaneous radionuclides. The primary nuclide of concern for the hot lab and senior cave was ${ }^{137} \mathrm{Cs}$. 
Cyclotron D\&D Project

Final Report

Page 3 of 43

\subsection{FACILITY DESCRIPTION AND HISTORY}

\subsection{Facility Background}

The 60" Cyclotron was built in 1951; it was test run and accepted on July 10, 1952. The facility was operated for research and medical radioisotope production until November 30, 1992.

The facility consisted of the Cyclotron and support areas shown in Figures 3.1 and 3.2 The Cyclotron areas included a two-level Cyclotron vault space (C-001 and C-101); a mechanical equipment room (A-011); deflector vault (A-033, A-004, and A-020); control room (B-102); electrical equipment rooms (A-111 and A-119); radiochemical laboratories (B-105, B-109, and B-113); dark room/animal room/mechanical laboratory (B-121 and B121A); counting room (B-101); experimental tunnel (B-140); and a hot lab, consisting of the senior cave operating room (B-118), junior cave operating room (B-126), and a senior and junior caves service room (B-124).

\subsection{Physical Location}

The Cyclotron facility was located on the ANL-E site in the 200 West Area (Building 211). The ANL-E site is located approximately 22 miles southwest of downtown Chicago and 25 miles west of Lake Michigan at the nearest point. Access to the site is provided by State Highway 83, Westgate Road, Lemont Road, Northgate Road, and Cass Avenue, all having access with Interstate Highway 55 . The areas south and west are primarily rural, with the more heavily populated areas to the north and west. The 2,040 acre Waterfall Glen Forest Preserve, a greenbelt forest preserve in the DuPage County Forest Preserve District, surrounds the ANL-E site. The Des Plaines River, the Chicago Sanitary and Ship Canal, and the Illinois Waterway (Illinois and Michigan Canal) are all located about one mile beyond the southern boundary of the Laboratory site. The Laboratory occupies a 1,275-acre reservation in DuPage County, Illinois, with 200 acres of operational facilities and the remaining 1,075 acres devoted to landscaping and forest (Figure 3.3). ANL-E is located in the southeast corner of DuPage County, Illinois, roughly 25 miles from the Chicago city limits. It is situated between I-55 to the north, the Des Plaines River to the south, Lemont Road to the west, and Cass Avenue to the east. ANL-E covers approximately 1,500 acres and is surrounded by the Waterfall Glen Forest Preserve.

Approximately 4,000 employees work at the ANL-E site. Currently, Building 211 houses the Chemistry Division's Linear Accelerator (LINAC) facility in a separate wing. The majority of work described in this report took place inside the facility. D\&D project staff offices and contractor personnel were housed in the A-wing area of Building 211.

Access to Building 211 is by paved road from the southwest area of the Inner Circle Road to the front and by paved road off the southwest area of the Outer Circle Road to the rear of the facility. 


\section{Cyclotron D\&D Project}

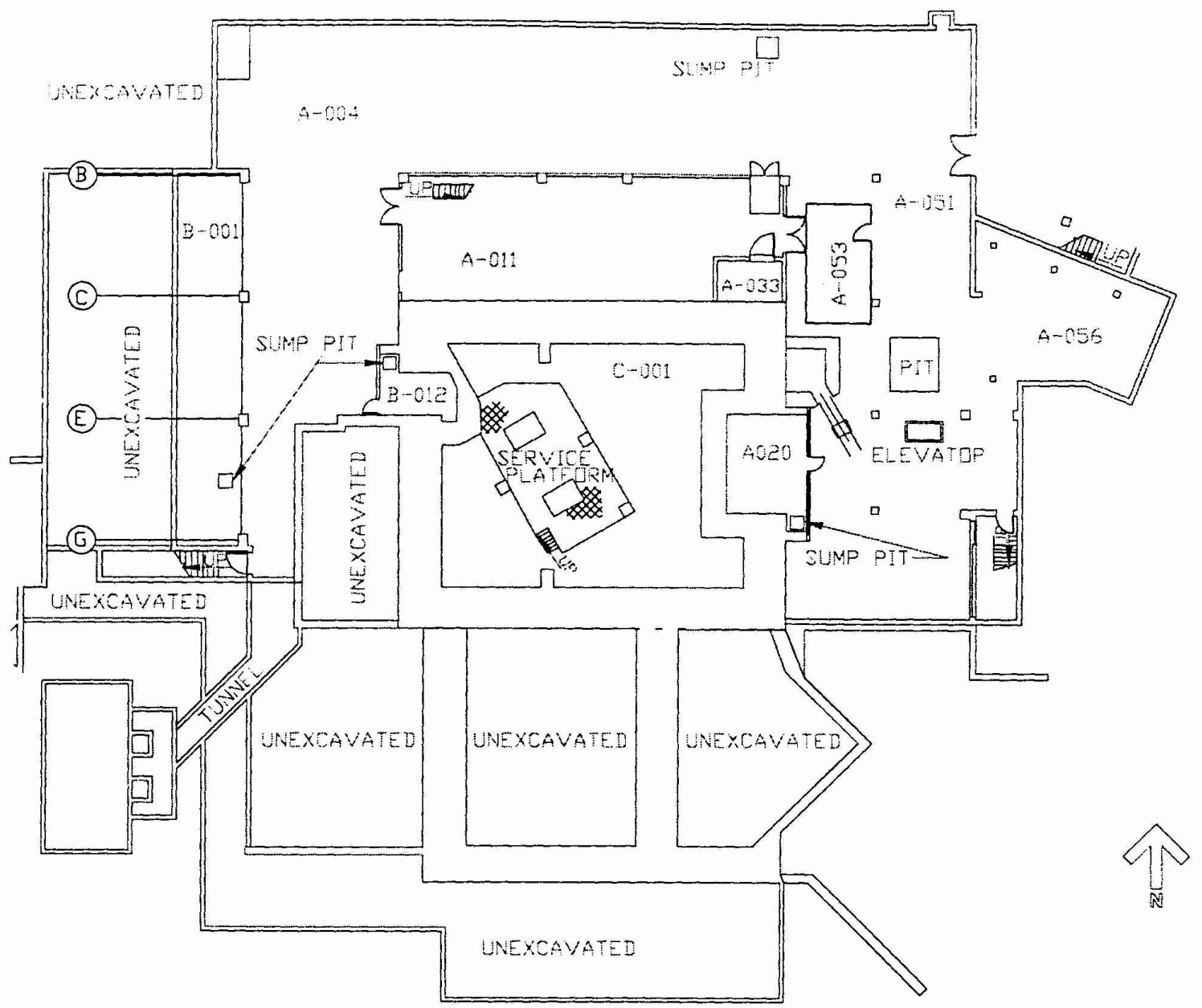

Figure 3.1 Building 211 Cyclotron Facility, Service Floor 


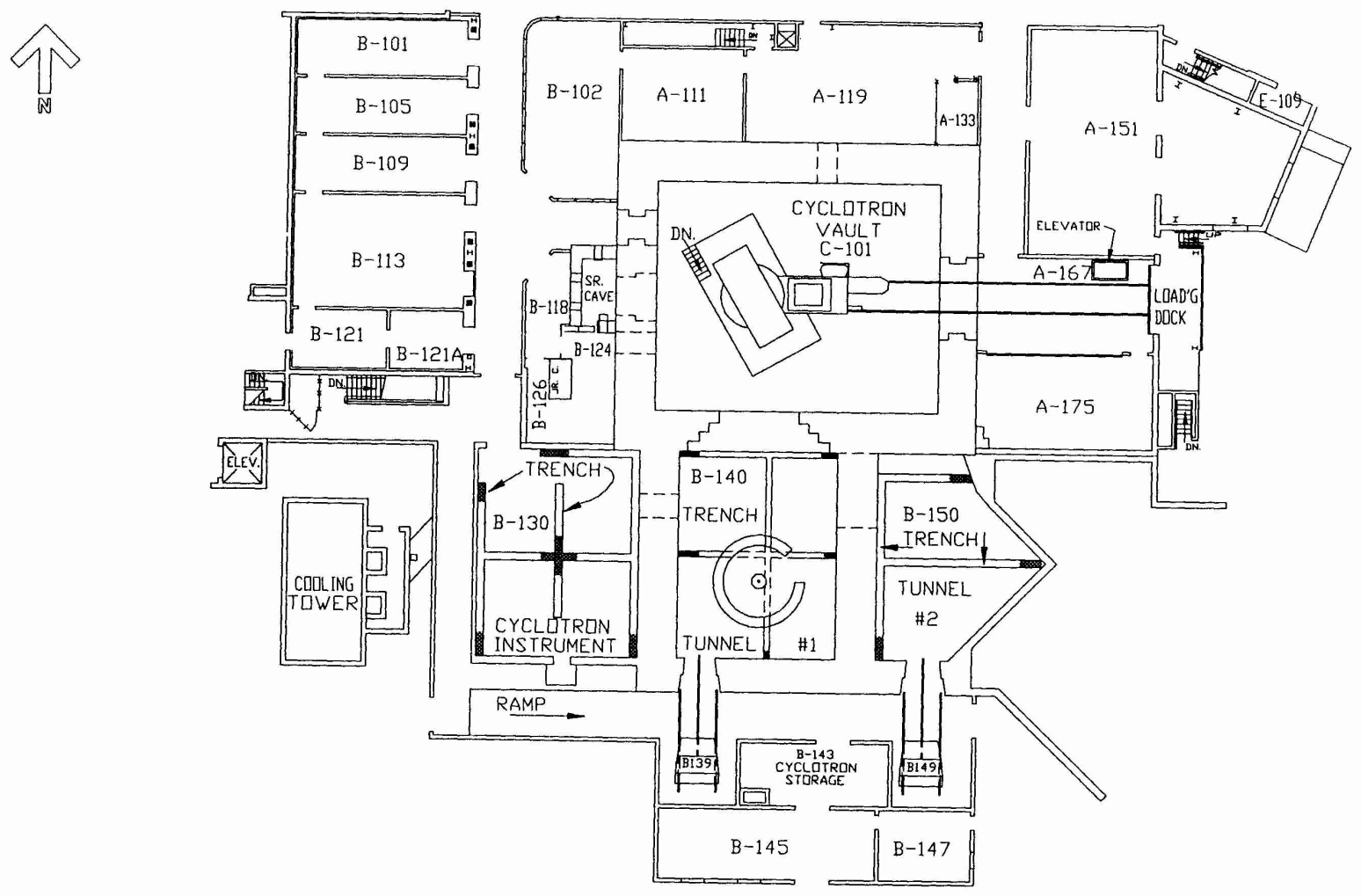

Figure 3.2 Building 211 Cyclotron Facility, Main Floor 
Cyclotron D\&D Project

Final Report

Page 6 of 43

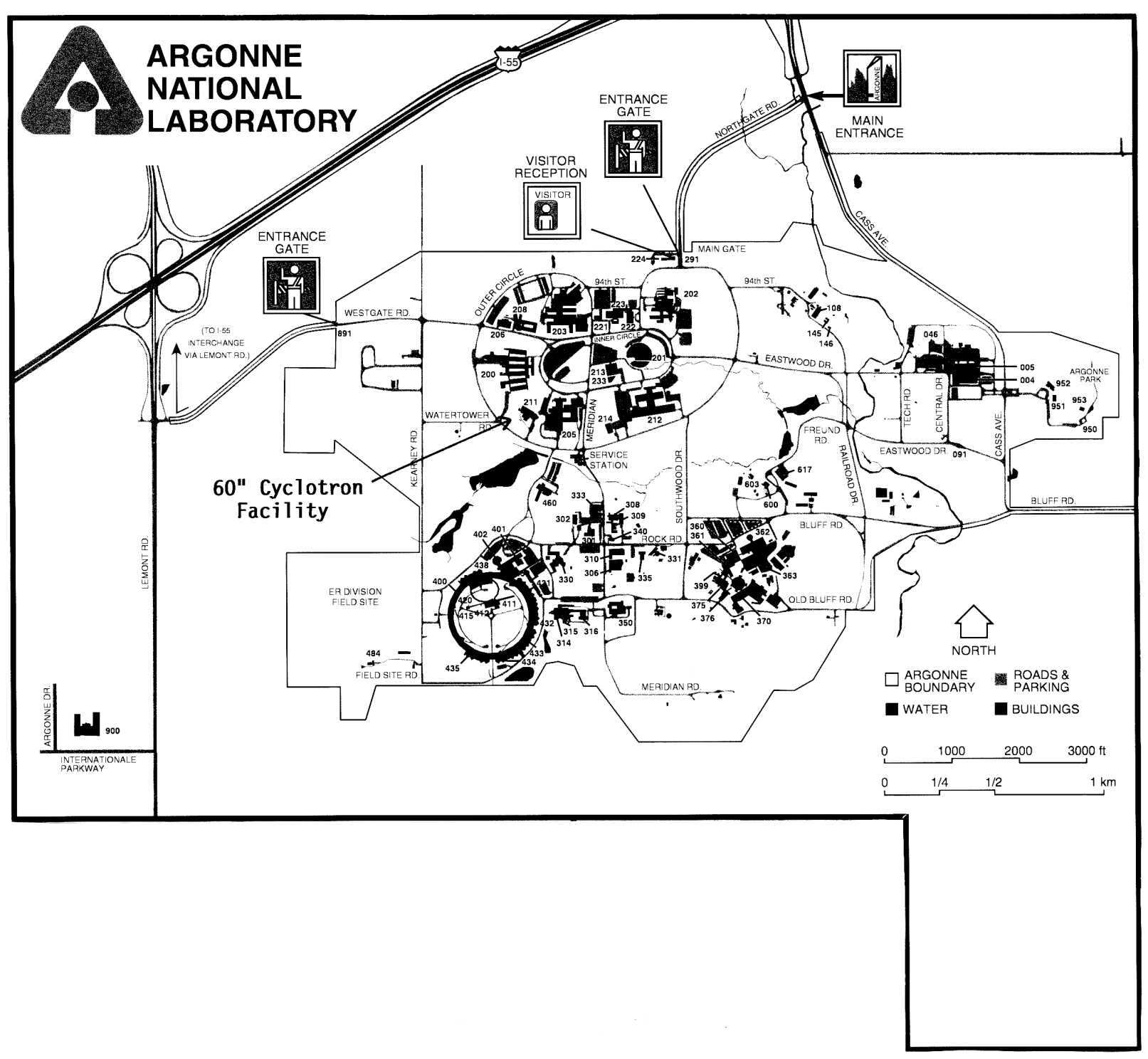

Figure 3.3 ANL-E Site Map 
Cyclotron D\&D Project

Final Report

Page 7 of 43

\subsection{Architectural/Engineering Information}

\subsubsection{General Statement}

Building 211 was originally designed and built to house the 60 " Cyclotron. The 265 -ton magnet was assembled in place, and the building was constructed around this assembly.

\subsubsection{Description of the 60" Cyclotron and Supporting Features}

\subsubsection{Cyclotron}

The 60" Cyclotron was a fixed frequency machine capable of accelerating beams of singly charged hydrogen molecules, deuterons, ${ }^{3} \mathrm{He}$, and ${ }^{4} \mathrm{He}$ ions to $11,21,34$, and $45 \mathrm{MeV}$, respectively. Early work encompassed the fields of heavy element chemistry, nuclear activation studies, nuclear scattering, solid state physics, radiation chemistry, isotope production, and biological studies.

The Nuclear Medicine Group (NMG was a significant subsequent user of the facility. Their major use of the Cyclotron was for the production of ${ }^{211} \mathrm{At}$ by the ${ }^{209} \mathrm{Bi}(\alpha, 2 \mathrm{n})$ reaction. In addition, the NMG also produced ${ }^{18} \mathrm{Fe},{ }^{44} \mathrm{Sc},{ }^{46} \mathrm{Sc},{ }^{47} \mathrm{Sc},{ }^{47} \mathrm{Ca},{ }^{64} \mathrm{Cu},{ }^{62} \mathrm{Zn},{ }^{114} \mathrm{In},{ }^{205} \mathrm{Bi}$, and ${ }^{206} \mathrm{Bi}$. Other users were the ANL-E Physics Division $\left({ }^{56} \mathrm{Co}\right.$ and ${ }^{178} \mathrm{Hf}$ production), and Oak Ridge National Laboratory $\left({ }^{237} \mathrm{Pu}\right.$ production).

\subsubsection{Cyclotron Vault}

- Main Floor (C-101) - The Cyclotron vault is $40 \mathrm{ft}$ by $50 \mathrm{ft}$ with a ceiling height of $28 \mathrm{ft}$, where a 10-ton precision-hoist bridge crane was installed. The vault walls are 7-ft thick, of $150 \mathrm{lb} / \mathrm{ft}^{3}$ concrete; the ceiling is $4-\mathrm{ft}$ thick, of the same density concrete. The two hydraulically operated access doors vertically raised and lowered to allow passage of personnel and equipment. The personnel door, weighing about 38 tons, could be closed in one minute and opened in 30 seconds. The 120-ton DEE door could be closed in five minutes and opened in one minute. The "DEE" designation came from the half-pill-box shape of the hollow metal chamber that is the heart of every cyclotron. Originally, there were two viewing windows, one to the hot lab, the other to the electrical equipment room (A-119); the latter was later drained, filled with sand, and blanked off with metal plates.

- Service Floor (C-001) - Located below the main floor, the service floor had the same floor area with 7-ft-thick walls. Access was only through the main floor via a stairwell adjacent to the Cyclotron magnet. There were also two lifting plugs in the northeast and southeast corners, allowing the bridge crane located in the main floor ceiling to lower and raise heavy items to and from the service floor. The concrete foundation of the 265-ton magnet, the lower portion of the magnet, and miscellaneous support equipment were located in this area. 


\subsubsection{Hot Lab (B-118- B-126)}

The hot lab was a HEPA-ventilated room that contained a junior cave, senior cave, and a viewing window to the main floor of the vault. There was a one-ton overhead crane that was used primarily for lifting heavy items out of the senior cave through removable roof blocks. The room also contained three fume hoods, radioactive material storage tubes in the east wall, and a contaminated drain sump from the sinks in the adjacent laboratory (B-130).

- Junior Cave - comprised 3-in-thick steel walls, a 9-in-thick lime glass viewing window, and one pair of Model 7 master-slave manipulator arms. The inside working surface was 20 in $\times 48$ in and was HEPA exhausted. Access to the cave was by a removable back wall suspended from a pair of trolley beams and rollers.

- $\quad$ Senior Cave - contained a HEPA-exhausted $6 \mathrm{ft} \times 10 \mathrm{ft}$ working area. A target transfer slot was used to transfer targets directly from the Cyclotron vault. Material was handled by two pairs of Model 8 master-slave manipulator arms and stored in 6-in-diameter sleeves cast into the cave wall. The walls were 24 -in-thick ferro-phosphorous concrete with a density of $300 \mathrm{lb} / \mathrm{ft}^{3}$.

\subsubsection{Basement}

Areas A-011 and A-033, located outside the north wall of the service floor, contained mechanical vacuum pumps, a cooling water circulating system, a motor-generator set, auxiliary air compressor, and an oil-immersed deflector voltage power supply.

\subsubsection{Cyclotron Conditions after Deactivation}

The power supplies to the Cyclotron components were disconnected and terminated, the cooling system was drained, and various loose items were removed from the vault and service floor areas. The hydraulic personnel access door and DEE door were operational.

Legacy waste was left in the senior cave; there were unknown quantities of ${ }^{226} \mathrm{Ra},{ }^{243} \mathrm{Am},{ }^{90} \mathrm{Sr},{ }^{232} \mathrm{U}$, ${ }^{235} \mathrm{U},{ }^{238} \mathrm{U}$, and various other sources. The physical form for most of this waste was uncharacterized and unknown.

\subsection{PROJECT OVERVIEW}

The Cyclotron D\&D Project began in June 1997 with characterization, planning, and documentation activities. These were completed in December 1998. At the end of FY 1999, a subcontractor (MOTA Corporation, Columbia SC) was selected to complete the D\&D field work. 
Subcontractor mobilization took place in January 2000. The scope of the Cyclotron D\&D Project did not include the entire facility; some areas had previously been released by ANL-E Health Physics (ANL-E HP). The scope of this project included release of the following areas for reuse: Cyclotron vault (C-101, C-001); hot lab area, including junior and senior caves (B-118 - B-126) and the transit area to the vault from the hot lab; portions of the electrical equipment room (A-111, A-119); and portions of the mechanical equipment room (A-011) and deflector vault (A-033).

MOTA Corporation determined that the best way to size reduce the 265-ton magnet was by "coldcutting," which would avoid problems associated with airborne contamination, welding slag, and cleanliness control. MOTA subcontracted Reverse Engineering (Columbia, SC) to design and build a hydraulically driven, reciprocating saw with 108-in-long, 3/8-in-thick blades to size reduce the magnet. INSCO Saw, also from South Carolina, designed and custom built the blades.

The D\&D crew prepared support areas, performed initial radiological surveys of affected areas, and staged equipment. The primary activities that followed were removal of the Cyclotron support equipment and packaging as Low Level Radioactive Waste (LLRW), removal of asbestos pipe insulation in the A-011 area, and preparation of the Cyclotron magnet prior to mounting the saw.

The saw was first mounted on the magnet in April 2000; segmenting the magnet into pieces weighing approximately $16,000 \mathrm{lb}$. each was completed in November 2000 . The saw averaged a cut through the 31-in-thick, 74-in-wide magnet every seven working days.

Simultaneously, the junior cave was dismantled and size-reduced, the senior cave was decontaminated, and the vault and support areas were wiped down in preparation for the final status survey.

Grids were established, and a final status survey was performed. This survey was independently verified by ANL-E HP and by the Oak Ridge Institute for Science and Education (ORISE).

\subsection{PROJECT PLANNING AND ENGINEERING}

\subsection{Project Planning}

Preliminary project engineering included the development of a decommissioning plan and a cost estimate for the D\&D project. The decommissioning plan provided a prescribed methodology for performing project activities. This plan included an overview of the project, projected dismantling sequences projected schedule, anticipated health and safety considerations, and a preliminary environmental analysis. It also included recommendations for special equipment and supplies, and an anticipated job breakdown per task. The decommissioning plan was revised over the course of the project so that it contained current and accurate information. 
The total cost estimate was based on the planned activities of the project. The scope of the cost estimate included the derivation of the anticipated costs required to perform each D\&D task. Included in this estimate were costs for removal of the Cyclotron support equipment, size reduction of the 265-ton magnet, and decontamination and disposal of the hazardous waste in the hot lab area. Also, included were task durations; manpower requirements; and waste types and volumes for each work activity. The associated costs for labor and waste disposal were calculated, while costs not directly associated with individual work activities, such as engineering planning, were calculated as undistributed costs.

\subsection{Project Organization/Management}

The Cyclotron D\&D Project had a specific management structure in which administrative, programmatic, and technical responsibilities for the performance of the project were delineated, including management controls and reporting systems. The various organizations involved in this project and their responsibilities are described in this subsection.

The ultimate responsibility for accomplishment of the Cyclotron D\&D Project was with the Secretary of Energy. This responsibility passed through the Office of the Assistant Secretary for Environmental Management to the Office of the Deputy Assistant Secretary for Project Completion. The DOE Chicago Operations Office (DOE-CH) was designated as the Assigned Operations Office and the Argonne Area Office (DOE-AAO) had overall responsibility for the administrative, programmatic, contractual, technical, and fiscal aspects of the project. DOE-AAO monitored the performance of the Cyclotron D\&D Project on a periodic basis.

Argonne National Laboratory-East was assigned the lead role for the actual decommissioning of the Cyclotron. The Laboratory directed, managed, and controlled all phases of the work. The project manager was responsible for managing the day-to-day operations at the site, including the following tasks:

- $\quad$ Preparing the project plan, the project schedule, and the project budget and cost plan

- $\quad$ Preparing the project Quality Assurance Plan

- $\quad$ Obtaining and directing the project work force

- Monitoring and documenting the progress of the project and exercising cost control

- Arranging for radiation measurements and radionuclide identifications to determine the type and activity concentrations of the radioactive decommissioning waste

- $\quad$ Assuring that auditable records are maintained for:

- Radiological instrument surveys and smear surveys

- Air sampling data (both radiological and industrial)

- Radionuclide identification and concentrations

- Personnel radiation exposures

- Materials released for unrestricted use

- Materials packaged and sent for burial 
- Industrial hygiene and safety guidance, instruction, and training

- Developing work procedures

- Determining the disposition of all structures, materials, and equipment

- Physical decommissioning work

- Overseeing the handling and packaging of all decommissioning waste

- Documenting radioactive waste for off-site shipment and disposal

- Final radiological characterization of the facility

- $\quad$ Preparing the project final report

Figure 5.1 shows the relationship between DOE, ANL-E, and subcontractors. Subcontractors were used to perform various tasks related to this project. MOTA Corporation was hired to perform the D\&D activities and provide health physics support. Additional subcontractors were hired as needed. The ANL-E project manager was responsible for all subcontracting activities. Figure 5.2 shows the Cyclotron D\&D project organization.

\subsection{Project Engineering}

\subsubsection{Quality Assurance (QA)}

The project Quality Assurance (QA) Plan prescribed the requirements for achieving a satisfactory level of quality in the performance of project activities. These requirements were based upon existing codes, standards, and practices and most specifically on those found in the current issues of ANSI/ASME NQA-1 and DOE Order 5700.6C, the ANL-E QA Implementation Guide, and the ANL-E QA Planning Guide.

The following activities most relevant to D\&D operations were covered by the project QA Plan:

- Waste segregation as to radioactive and non-radioactive

- $\quad$ Packaging of radioactive waste

- Radioactive content of waste packages

- Instrument calibrations

- QA plan audits

QA responsibilities were delineated to project management personnel relative to the project QA plan. The project manager had overall responsibility for the execution of the project QA Plan and was assisted in carrying out specified QA requirements by the Technology Development (TD) Division quality assurance representative (QAR).

The Health Physics Supervisor was responsible for complying with the project QA Plan requirements for sampling, sample analysis, standards, instrument calibrations, radiation safety, radiation monitoring, and the final radiation survey of the facility. 


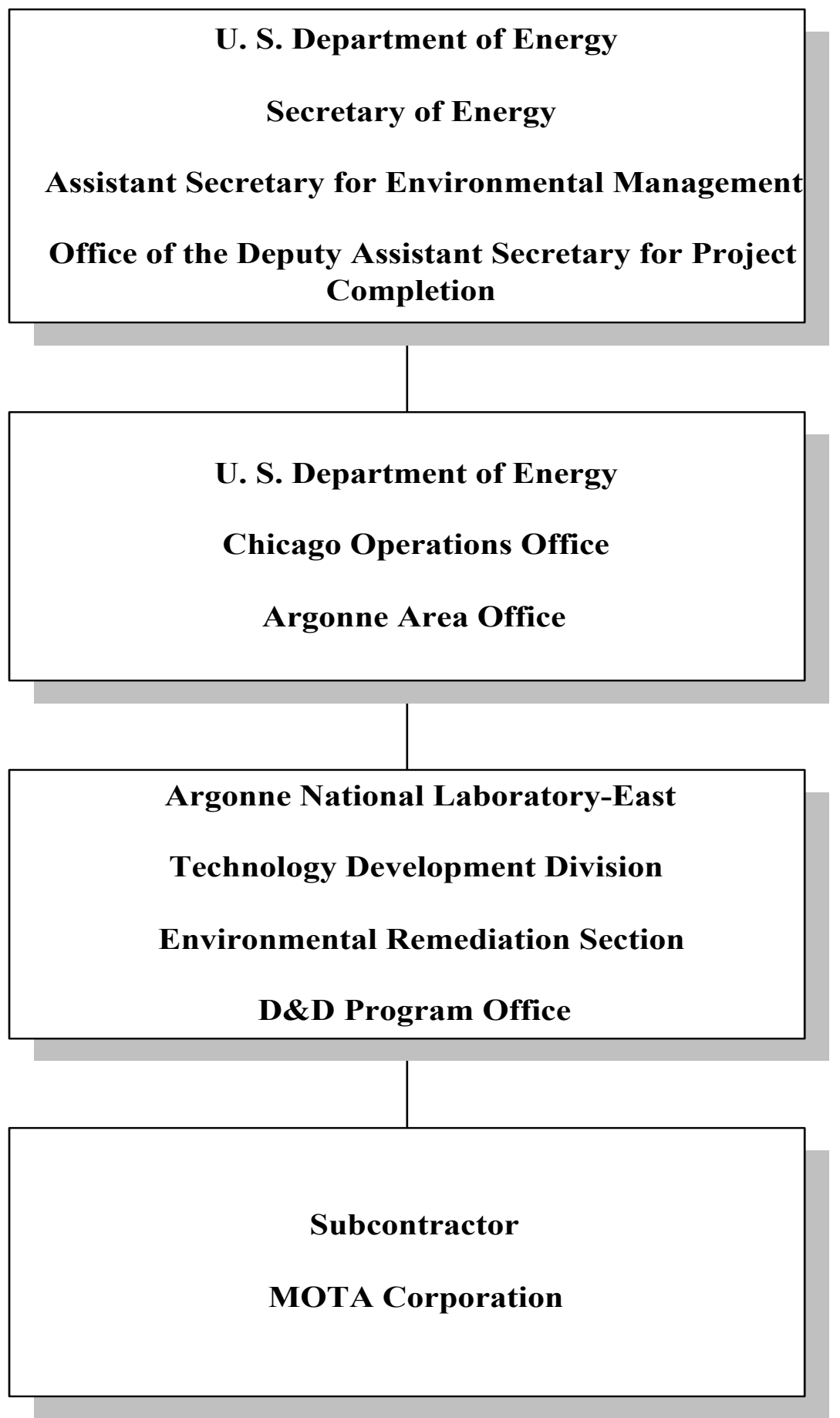

Figure 5.1 Relationship between DOE, ANL-E and Subcontractors 


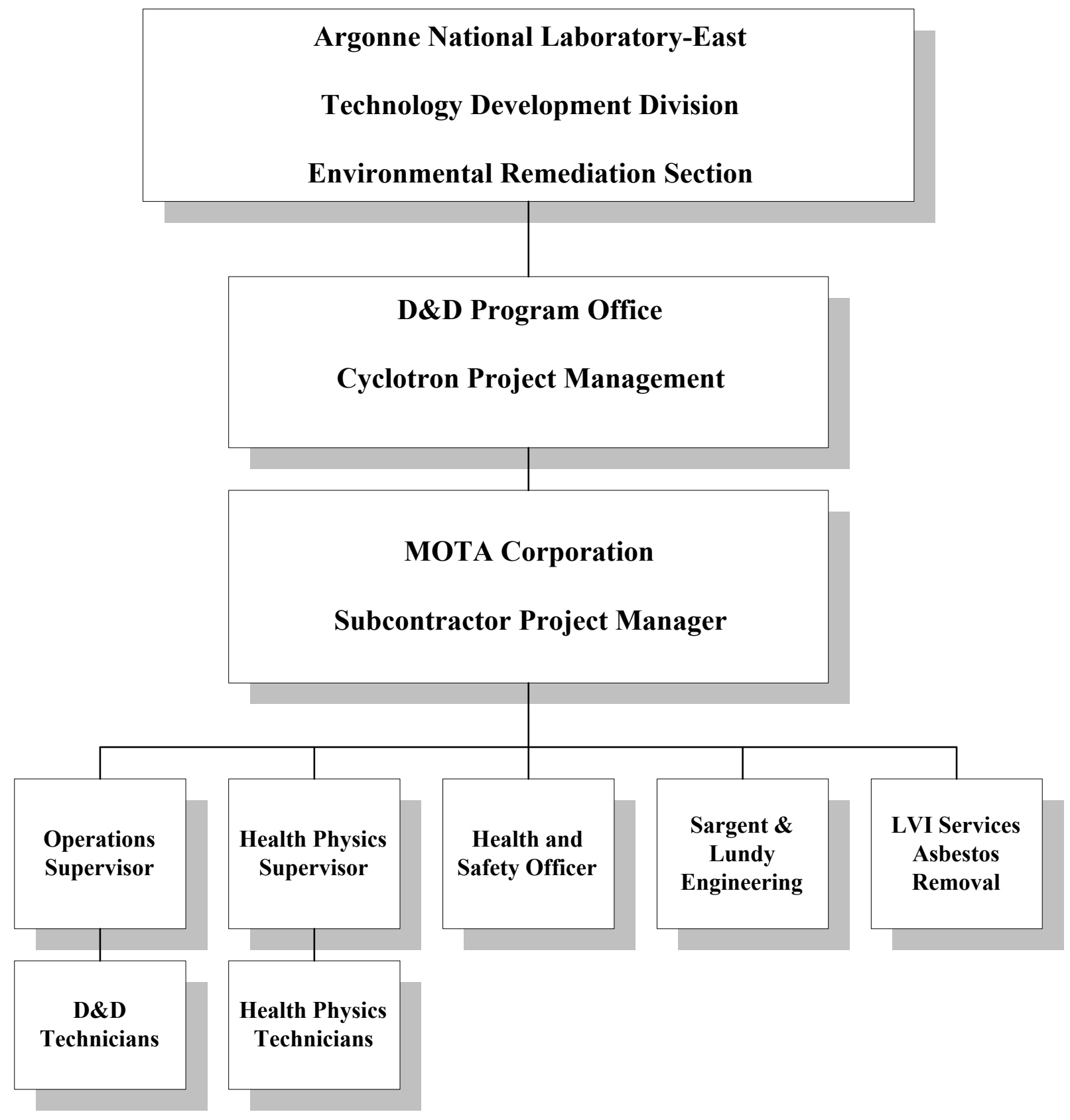

Figure 5.2 Cyclotron D\&D Project Organization 
The Plant Facilities and Services Waste Management Operations (PFS-WMO) QAR, the Environment, Safety and Health (ESH) Division QAR, and the TD QAR had joint responsibility for the review and approval of the QA Plan with respect to the project. They assisted the project manager in implementing the QA Plan and served as an interface with the ESH/QA Oversight Office.

ANL-E ESH/QA Oversight was responsible for auditing the project to verify compliance with the QA Plan and to determine its effectiveness. ANL-E ESH/QA Oversight reviewed QA plans prior to issuance and provided guidance and consultation to the Divisional QA Representatives. ESH/QA Oversight served as a third party, independent review of project QA.

\subsubsection{Project Control}

The Cyclotron D\&D project manager had prime control and overall responsibility for the project. Details of project activities were documented in weekly highlights and monthly progress reports that were submitted to DOE-AAO.

The project manager reviewed reports in order to identify any project deficiencies and scheduled periodic meetings of project personnel to assess progress and deal with any problems as they arose. Technology Development Division management performed routine project status review meetings to gauge project status and issues.

\subsubsection{Project Data}

Data generated during D\&D activities, including survey results, instrument calibrations, sample analyses, personnel radiation and toxic material exposures, etc., have been retained as permanent records of the project. Appropriate ANL-E management staff reviewed the data to assure that all operations were in compliance with QA Plan specifications. Periodic QA audits of the data were performed to verify such compliance.

\subsubsection{Training}

All project personnel involved with Cyclotron decommissioning work were previously trained and experienced in the tasks they performed. Personnel assigned special tasks with which they were unfamiliar, were given additional and specialized training by either project personnel or ANL-E training to enable them to perform the work safely and expeditiously.

All project personnel involved with the Cyclotron D\&D Project were required by ANL-E policy to meet minimum training requirements, as identified below: 
- For all personnel requiring unescorted access to the Cyclotron facility:

- ANL-E Contractor Safety Orientation

- ANL-E Radiological Worker II

- Occupational Safety and Health Administration (OSHA) 40-hour Hazardous Waste Site Operations (HAZWOPER)

- Building 211 Facility Orientation

- Conduct of Operations Training

- ANL-E Quality Assurance Plan Training

- For personnel assigned as health physics technicians and supervisors

- Qualified as a Radiological Control Technician at a DOE site

- For personnel assigned as Health and Safety Manager:

- OSHA Hazard Recognition for Construction

Training in other areas such as rigging and hoisting, respirator usage, industrial safety, etc., was provided on an as-needed basis to ANL-E and contractor personnel by those ANL-E organizations having expertise in such fields. This training included use of films and videos produced by various outside firms as appropriate to the project work.

\subsubsection{Health Physics}

The health physics personnel from MOTA Corporation were employed to monitor the radiological aspects of the project. These personnel had formal training in their fields of specialization and had practical and varied radiation monitoring skills. Final release of items and material from controlled areas were $100 \%$ verified by ANL-E health physics personnel, with reviews of survey results and oversight from an ANL-E Area Health Physicist.

\subsubsection{Health and Safety}

\subsubsection{Environment, Safety, and Health Policy}

The MOTA Corporation Health and Safety Manager was responsible for the health and safety aspects of the Cyclotron D\&D Project. MOTA Corporation was contractually required to comply with the ANL-E ESH Manual. The project Health and Safety Plan was reviewed by ANL-E ESH and was in compliance with the ANL-East ESH Manual. The ESH Division provided staff members specializing in the areas of health physics, industrial hygiene, and safety engineering to monitor and assist the project for the purpose of identifying and evaluating conditions that might have affected health and safety. 


\subsubsection{Radiation Safety}

Data concerning the radiological exposure of project personnel were collected, recorded, and analyzed by members of ESH. Project health physics personnel made recommendations regarding project safety procedures and criteria for D\&D activities as well as for radioactive waste disposal. They also reviewed project work procedures and monitored project activities with the objective of identifying potential radiological hazards and eliminating or controlling them. These recommendations embodied the "As Low As Reasonable Achievable" (ALARA) principle.

\subsubsection{Industrial Hygiene}

Staff members of ESH/Industrial Hygiene furnished technical guidance in the areas of toxic material handling, respiratory protection, ventilation, and protective clothing. Additionally, they performed HEPA filter and respiratory testing, monitored for toxic material exposures, and gave training in respirator usage. Data obtained from these activities were evaluated to determine if further mitigating measures were needed and retained as part of the permanent project records.

\subsubsection{Industrial Safety}

Staff members of ESH/Safety Engineering reviewed the industrial safety aspects of the project. They evaluated the potential exposure of personnel to accidental injury hazards and recommended methods to minimize such occurrences.

\subsubsection{Fire Protection and Security}

Project fire protection services and safety guidance were provided by the ANL-E Fire Department. They made periodic tours of the work site to assess fire potential and advised Cyclotron D\&D project management on potential improvements. The Laboratory contractor security force provided physical security.

\subsection{Conduct of Operations}

The Technology Development Division Decontamination and Decommissioning Conduct of Operations Manual was followed during the Cyclotron D\&D Project. The manual establishes guidelines for the eight elements of a Conduct of Operations Program. These include:

- Operations organization and administration

- Communications

- Investigation of abnormal events

- Control of equipment and system status

- $\quad$ Log-keeping

- Postings 
- $\quad$ Labeling

- Operations essential to ensure safe and timely progress during the Cyclotron D\&D

\subsection{Site Characterization}

A characterization was performed from October 1997 to March 1998. The objective of this assessment was to determine the inventory and distribution of radioactive and other hazardous materials within the facility. Samples were taken of Cyclotron components, and concrete cores were bored from the vault wall where the possibilities of activation from the particle beam were highest. Various hazardous materials were sent for isotopic analysis. The Characterization Report and the Characterization Report Quality Assurance Plan required that extensive chemical analyses be made of the hazardous materials; however, these analyses were not performed. This deficiency was not noted in the Characterization Report. This problem is documented in a Non-Conformance Report, NCR-1868, and is discussed further in section 13.1.1 of this report.

Radiation and contamination surveys showed alpha/beta contamination of the hot lab, senior cave, and junior cave ductwork. The three fume hoods in the hot lab and the roof of the senior cave showed significant alpha/beta contamination. There was over $10^{6} \mathrm{dpm}$ loose alpha contamination found on the roof of the senior cave.

There were numerous radioactive sources in various types of containers in the senior cave. The items of most concern were listed in the Characterization Report as ".5 Ci Ra-226" and "glass bottle containing 2 grams Am-243." The inventory in the Characterization Report proved to be inaccurate, and this is discussed further in section 6.3.3.3 of this report.

Based on sample analysis, the estimated total activity in the Cyclotron magnet was $2.7 \times 10^{-6} \mathrm{Ci}$, with ${ }^{60} \mathrm{Co}$ activation of the 265 -ton magnet contributing nearly $97 \%$.

The Characterization Report identified that nearly all of the paint was lead-based. There were several small areas requiring asbestos controls in removing pipe insulation and floor tile.

\subsection{DECOMMISSIONING OPERATIONS}

\subsection{General}

In October 2000, MOTA Corporation was awarded a subcontract to perform the D\&D of the Cyclotron facility. The following sections detail the site conditions found upon mobilization, the instruments used in daily activities associated with all subcontractor work, and radiological conditions and incidents that occurred during the D\&D. 


\subsection{Preparatory Activities}

Preparatory activities included a review of all existing documentation, reports, and radiological surveys.

A base of operations was established in the A-wing vicinity of the work site. The base included offices; locker and shower facilities; storage space for equipment tools and materials; shop space; and a Project Management Office. No additional emergency or temporary power/light services were needed because the original electrical systems were intact. A liaison with appropriate ANL-E organizations was established to coordinate the provision of laboratory services to the project. These included emergency and medical services (i.e., ambulance, fire protection, medical personnel, and rescue equipment).

All project personnel were trained prior to the start of work activities. Additional new staff were trained as they were added to the project. Radworker Training II, OSHA, and other required training were provided at this time. Personnel who had completed this training previously were verified to be current, or they could take challenge tests, when appropriate. Training in specific project operations was provided at this time and later, as required.

Project supplies, including tools, equipment, decontamination materials, and radioactive-waste shipping containers, were procured at this time. Miscellaneous activities, including re-certifying the vault crane, connecting an independent $480 \mathrm{~V}$ power distribution system to the building substation, and performing necessary safety-related construction activities, were completed.

Radiological surveys of the controlled areas were performed for preparation of the radiological work procedures under which the D\&D activities would be performed. A controlled area for temporary storage of packaged containers awaiting shipment was established in the yard southeast of the loading dock.

\subsection{Radiological Conditions and Activities}

\subsubsection{Instrumentation and Equipment}

Instrumentation utilized during the work phase is listed in Table 6.1. 
Cyclotron D\&D Project

Final Report

Page 19 of 43

Table 6.1 Contractor Instrumentation Used During D\&D

\begin{tabular}{||l|l|l|l|l||}
\hline Measurement Type & \multicolumn{1}{|c|}{ Detector Type } & \multicolumn{1}{|c|}{$\begin{array}{c}\text { Detector Area; } \\
\text { Density }\end{array}$} & $\begin{array}{c}\text { Manufacturer/Model } \\
\text { No. }\end{array}$ & \multicolumn{1}{c||}{ Units } \\
\hline \hline Surface Alpha & Scintillation & $100 \mathrm{~cm}^{2} ; 0.8 \mathrm{mg} / \mathrm{cm}^{2}$ & Ludlum $43-90$ & $\mathrm{cpm}$ \\
\hline $\begin{array}{l}\text { Surface } \\
\text { Beta/Gamma }\end{array}$ & Geiger-Mueller & $16 \mathrm{~cm}^{2} ; 1.8 \mathrm{mg} / \mathrm{cm}^{2}$ & Ludlum $44-9$ & $\mathrm{cpm}$ \\
\hline $\begin{array}{l}\text { Removable Surface } \\
\text { Alpha/Beta/Gamma }\end{array}$ & Gas Proportional & $25 \mathrm{~cm}^{2} ; 80 \mu \mathrm{gg} / \mathrm{cm}^{2}$ & Protean $/ \mathrm{MPC}-9400$ & $\mathrm{dpm}$ \\
\hline $\begin{array}{l}\text { Surface } \\
\text { Alpha/Beta/Gamma }\end{array}$ & $\begin{array}{l}\text { Dual Phosphor } \\
\text { Scintillation }\end{array}$ & $100 \mathrm{~cm}^{2} ; 0.8 \mathrm{mg} / \mathrm{cm}^{2}$ & Ludlum $43-89$ & $\mathrm{cpm} / \mathrm{dpm}$ \\
\hline Exposure Gamma & NaI(Tl) & $1 \mathrm{in} \times 1 \mathrm{in} ; \mathrm{N} / \mathrm{A}$ & Ludlum M-19 & $\mu \mathrm{Rem} / \mathrm{hr}$ \\
\hline Exposure Gamma & $\begin{array}{l}\text { Geiger-Mueller, } \\
\text { energy compensated }\end{array}$ & $\mathrm{N} / \mathrm{A} ; 30 \mathrm{mg} / \mathrm{cm}^{2}$ & Ludlum 44-38 & $\mathrm{mR} / \mathrm{hr}$ \\
\hline Exposure Gamma & Ion Chamber & $40 \mathrm{~cm}^{2} ; 7 \mathrm{mg} / \mathrm{cm}^{2}$ & Ludlum M-9 & $\mathrm{mR} / \mathrm{hr}$ \\
\hline
\end{tabular}

\subsubsection{Radiological Conditions}

\subsubsection{Dose Rates}

The highest dose rate encountered was during handling of the ${ }^{226} \mathrm{Ra}$ source from the senior cave. A vial was measured at $250 \mathrm{mR} / \mathrm{hr}$ on contact during re-packaging. The Characterization Report referenced a $1.6 \mathrm{R} / \mathrm{hr}$ radiation reading in close proximity to the "splitter" in the Cyclotron Dee assembly, but this was removed prior to the start of D\&D operations by ANL-HP. The dose rates encountered, with the exception of the collected sources from the senior cave, were less than $0.1 \mathrm{mR} / \mathrm{hr}$. The general area dose rate around the collected sources was approximately $5 \mathrm{mR} / \mathrm{hr}$.

\subsubsection{Contamination Levels}

Smearable contamination was less than $1000 \mathrm{dpm} / 100 \mathrm{~cm}^{2}$ beta/gamma, and less than $20 \mathrm{dpm} / 100 \mathrm{~cm}^{2}$ alpha in the majority of the Cyclotron vault, with only a few isolated spots exceeding these values. The hot lab had numerous spots that exceeded these values; the three fume hoods contained levels of up to $10^{5} \mathrm{dpm} / 100 \mathrm{~cm}^{2}$ beta/gamma and $1,000 \mathrm{dpm} / 100 \mathrm{~cm}^{2}$ alpha. The senior cave ductwork contained approximately $5 \times 10^{5} \mathrm{dpm} / 100 \mathrm{~cm}^{2}$ fixed alpha contamination, and a "pass-through" tube for samples was contaminated with over $10^{6} \mathrm{dpm} / 100 \mathrm{~cm}^{2}$ fixed beta/gamma. 


\subsubsection{Airborne Activity}

All areas were continuously monitored for radiological airborne contamination; there was one occurrence of elevated Radon activity, released during re-packaging of the ${ }^{226} \mathrm{Ra}$ source. This incident is discussed in detail in section 6.3.3.3.

\subsubsection{Radiological Incidents}

\subsubsection{Removal of Activated Aluminum Off-Site}

On March 12, 2000, the subcontractor project manager removed 1,563 lb of slightly activated $(0.33 \mathrm{pCi} / \mathrm{g})$ aluminum scrap from the controlled area. Acting entirely on his own, he performed no surveys prior to removing the material, nor was ANL-HP involved in any way to perform the required survey. The material was not releasable under current DOE guidelines due to volume activation.

The subcontractor project manager's personal truck was at his residence with the material in the truck bed. The material was brought back on site and packaged as LLRW. The truck and surroundings were surveyed by ANL-HP. The subcontractor project manager was relieved of his duties and escorted off site. DOE issued a Preliminary Notice of Violation against MOTA Corporation. The motives for the theft of scrap aluminum are unknown.

This was considered a case of a single employee acting on his own. Other than more stringently controlling subcontractor access to the project, no further actions were taken at the project level.

\subsubsection{Release of Activated I-Beam for Recycling}

Upon review of project documentation during a management assessment, it was discovered that a 17-ft-long trolley beam used to position Cyclotron magnets was inadvertently free released from the Cyclotron vault for unrestricted use. This free release survey was performed by ANL-HP on February 17, 2000; the error was discovered on May 24, 2000. The ANL-HP technician performed the survey and released the item based on surface contamination limits. No one specifically told the health physics technician that the trolley beam was volume activated. Subcontractor personnel performed a release survey prior to this, and thought the item was releasable. There are no free release criteria for volume-activated materials, so the item should not have left the controlled area without being identified as LLRW. A comprehensive, on-site search was performed, from which it was determined that the item had left ANL-E and went to a recycling facility.

Corrective actions included stopping all releases of items from controlled areas until 1) personnel were properly trained on volume activation and on the recently published DOE moratorium on release of metals for recycling, and 2) a thorough review of items that were released from the Cyclotron controlled area was performed. A detailed search was performed for items that at one time 
might have been in the controlled area and that were potentially activated due to composition. This included items that were outside of the controlled area before the TD D\&D group took control of the area. Any items that were found to meet the criteria were returned to the area and packaged as LLRW.

This issue was addressed on a lab-wide basis by providing additional training for HP and examining free release policies at other facilities where activation could be an issue.

\subsubsection{Unplanned Release of Radon Gas}

On October 26, 2000, miscellaneous sources were repackaged. One of the sources was identified in the Characterization Report as ".5 Ci Ra-226." While handling this source, radon gas (the decay daughter of radium) was released, resulting in unplanned personnel exposure. The highest exposure estimated was 106 mrem whole body dose. During the investigation, it was determined that significantly less ${ }^{226} \mathrm{Ra}$ was present than the container label and Characterization Report had indicated. The exact amount is not known at this time, but the likely amount is between $5.6 \times 10^{-4}$ and $5.0 \times 10^{-3} \mathrm{Ci}$.

Corrective actions included preparation of a detailed procedure that became part of an RWP. This procedure received a laboratory-level ALARA review. The additional precautions included workers wearing self-contained breathing apparatuses, a tented "buffer zone," and proper ventilation of any possible release of radon gas.

\subsection{D\&D Activities}

\subsubsection{Initial Activities}

After the preparatory activities described in Section 6.2 were completed, the major D\&D activities remaining consisted of size reduction of loose material and non-installed equipment in the Cyclotron vault. These items were packaged as LLRW.

\subsubsection{Disassembly and Size Reduction of Cyclotron Support Components}

The Cyclotron vacuum system was removed by draining the oil in the mechanical pumps and diffusion pumps, and disassembling the "obround," vacuum take-off box, transition section, and all associated pumps, piping, and electrical components (see Figures 6.1 and 6.2).

The beam transport and analyzing system was removed by simply unbolting components and size reducing them in a HEPA-filtered, tented enclosure. The switching magnet was packaged in an LLRW bin; the two analyzing magnets were disassembled and painted as their own self-contained packages for LLRW disposal. 
Cyclotron D\&D Project

Final Report

Page 22 of 43

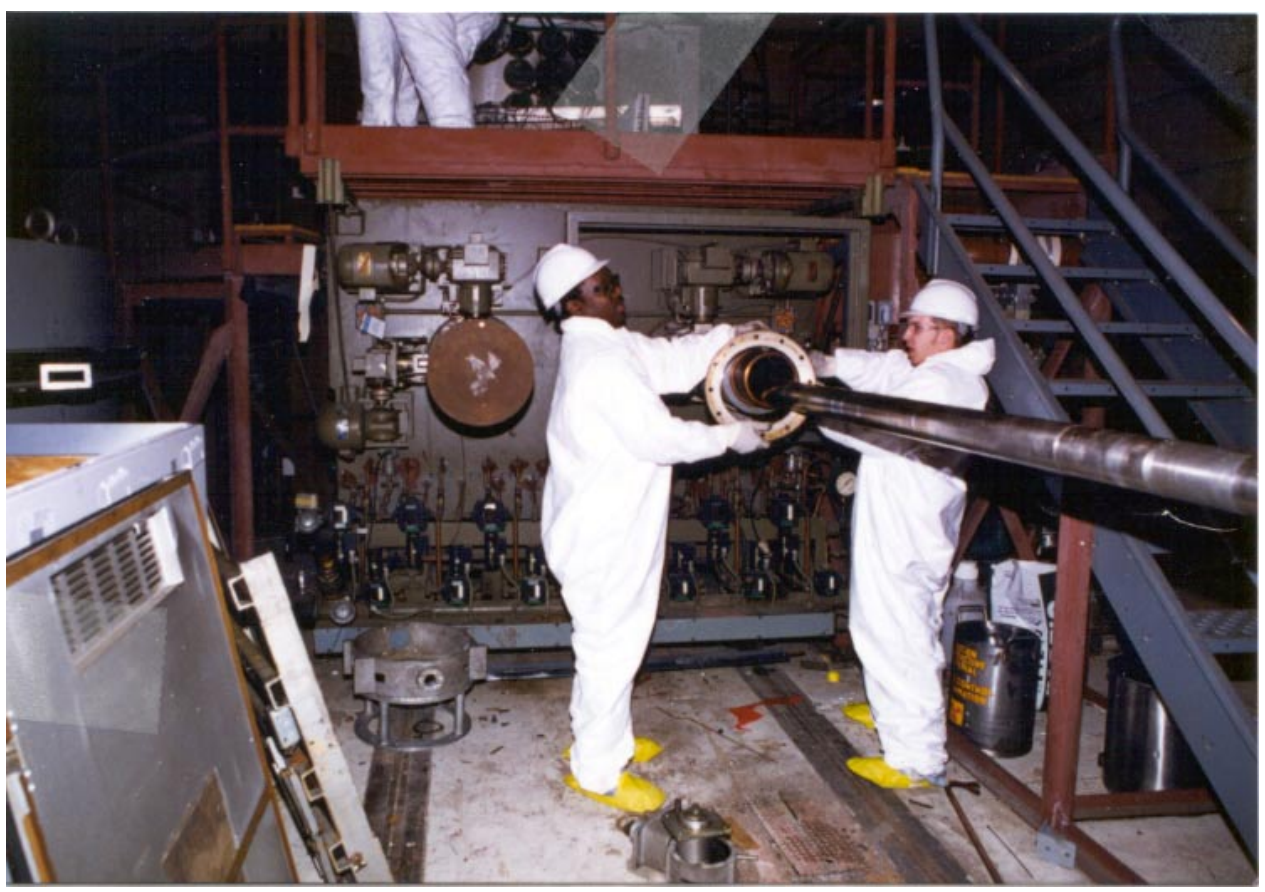

Figure 6.1 Disassembly and Removal of High-Voltage Transformer (ANL Neg. 25695K, Frame 20A)

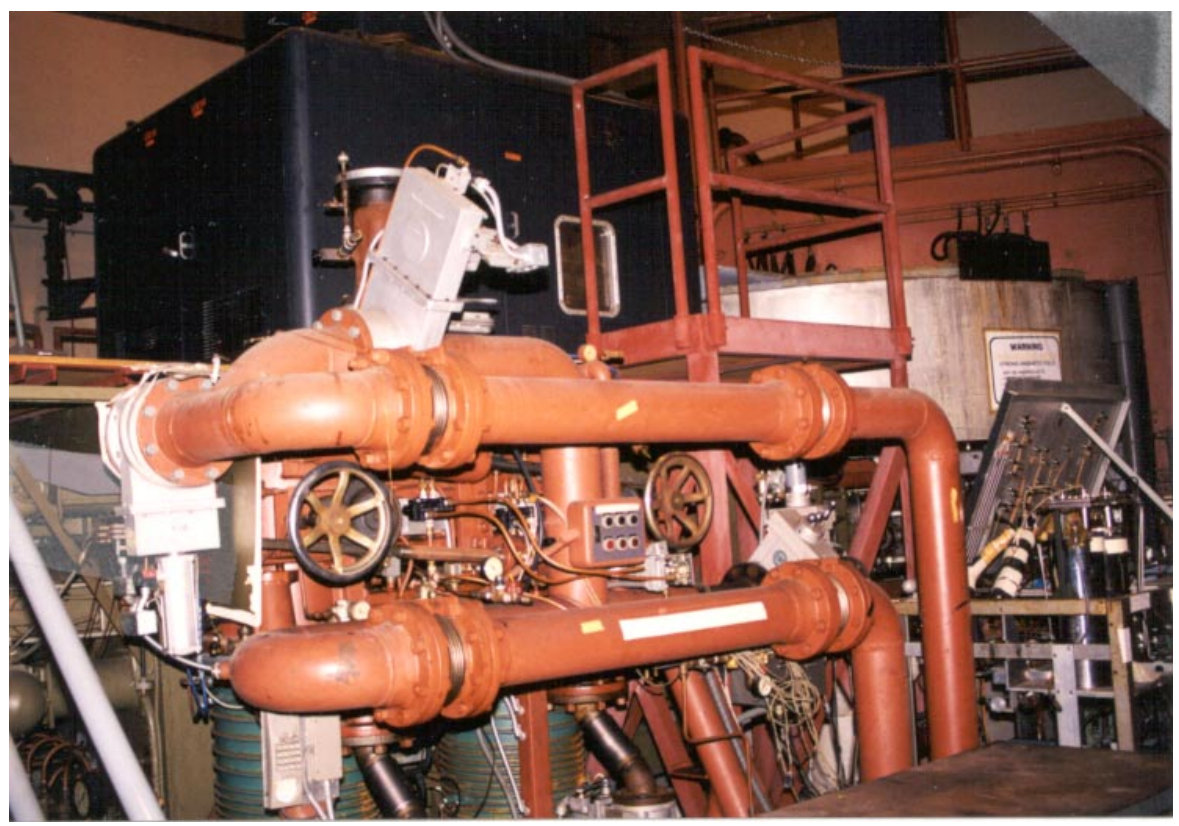

Figure 6.2 Cyclotron Piping was Disassembled and Size Reduced (ANL Neg. 25314K, Frame 17) 


\subsubsection{Cyclotron Dismantlement}

The accelerator chamber, Dees, and magnetic coils were dismantled and size reduced as LLRW (see Figure 6.3). The upper pole was supported by hydraulic jacks, unbolted, and lowered onto cribbing placed on the lower pole. The hydraulically operated reciprocating saw was then mounted to the upper yoke and used to sequentially size reduce the upper horizontal yoke (see Figures 6.4 and 6.5). A support structure, designed and certified by an Illinois-certified structural engineer, was built below the upper horizontal yoke to support the pieces as they were cut. After the upper horizontal yoke was segmented into eight blocks (each block was removed as it was cut), the saw was mounted with special curved brackets on the upper pole, which was then segmented with two 90-degree intersecting cuts. Once the cut pieces were removed, the lower pole was segmented. Because the lower horizontal pole interfered with the mounting of the saw, the lower pole was segmented using two parallel cuts. The saw was then mounted horizontally on the north vertical yoke, and the yoke was segmented with three horizontal cuts. The process was repeated for the south vertical yoke. Again, a certified structure was built underneath the lower horizontal yoke, and the last remaining section was cut into seven pieces in the same manner as the upper horizontal section. All yoke segments were painted and labeled as LLRW. Thirteen of twenty-four segments were recycled onsite; they will be used as shielding material at the Physics Division Argonne Tandem Linac Accelerator System. The remainder was shipped to Hanford as LLRW. The Cyclotron pedestal was left in place (see Figure 6.6).

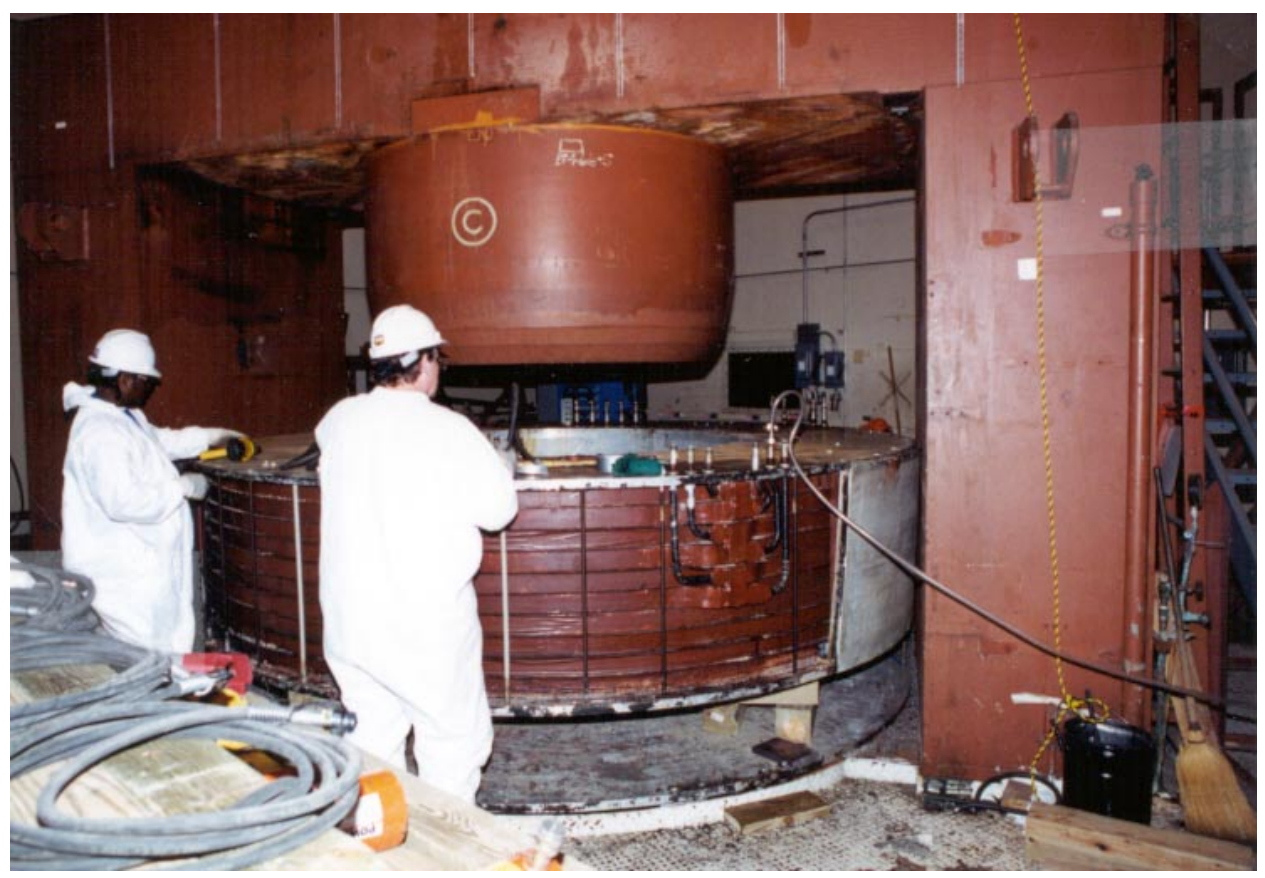

Figure 6.3 Once the Upper Magnet Coil was Lowered, the Outer Skin Was Removed (ANL Neg. 25777K, Frame 16) 


\section{Cyclotron D\&D Project}

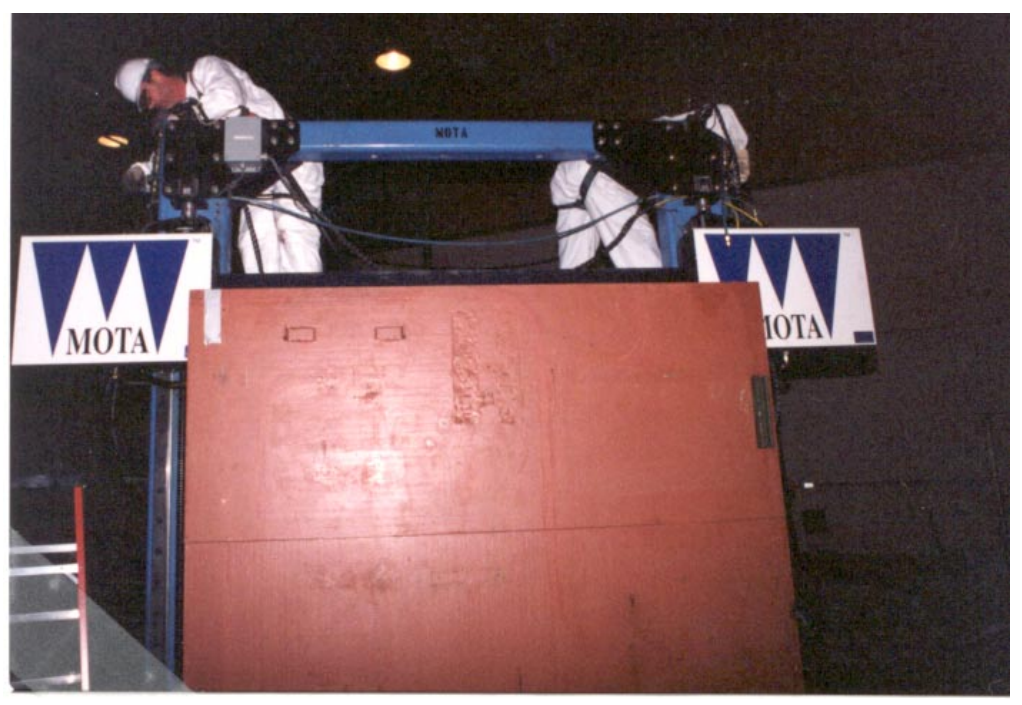

Figure 6.4 First the Saw Is Set In Place Over the Upper Yoke (ANL Neg. 25829K, Frame 6A)

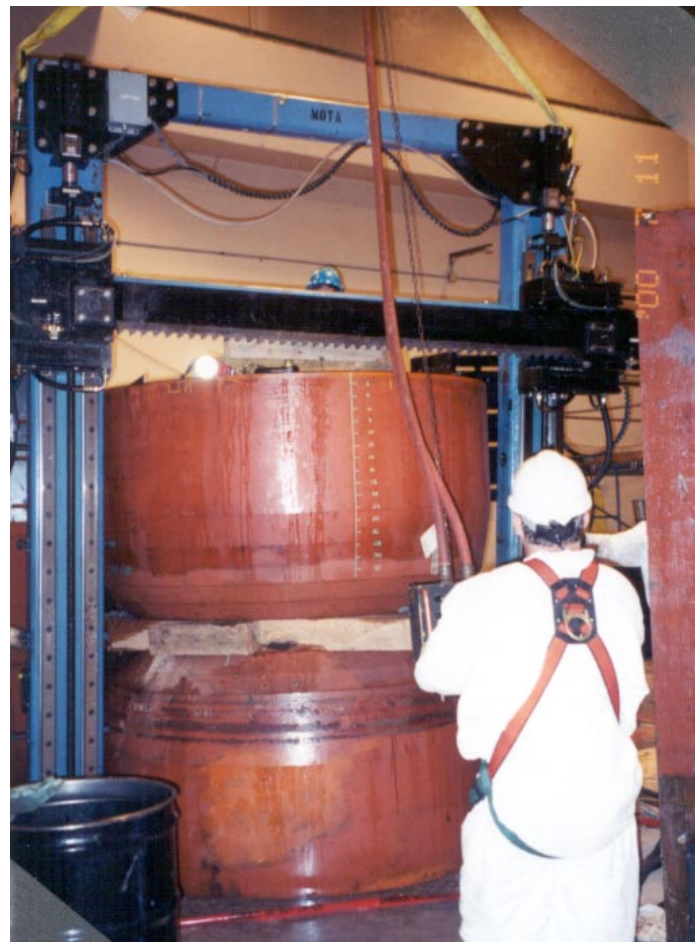

Figure 6.5 Then the Saw is Positioned (ANL Neg. 26012K, Frame 3A) 


\section{Cyclotron D\&D Project}

Final Report

Page 25 of 43

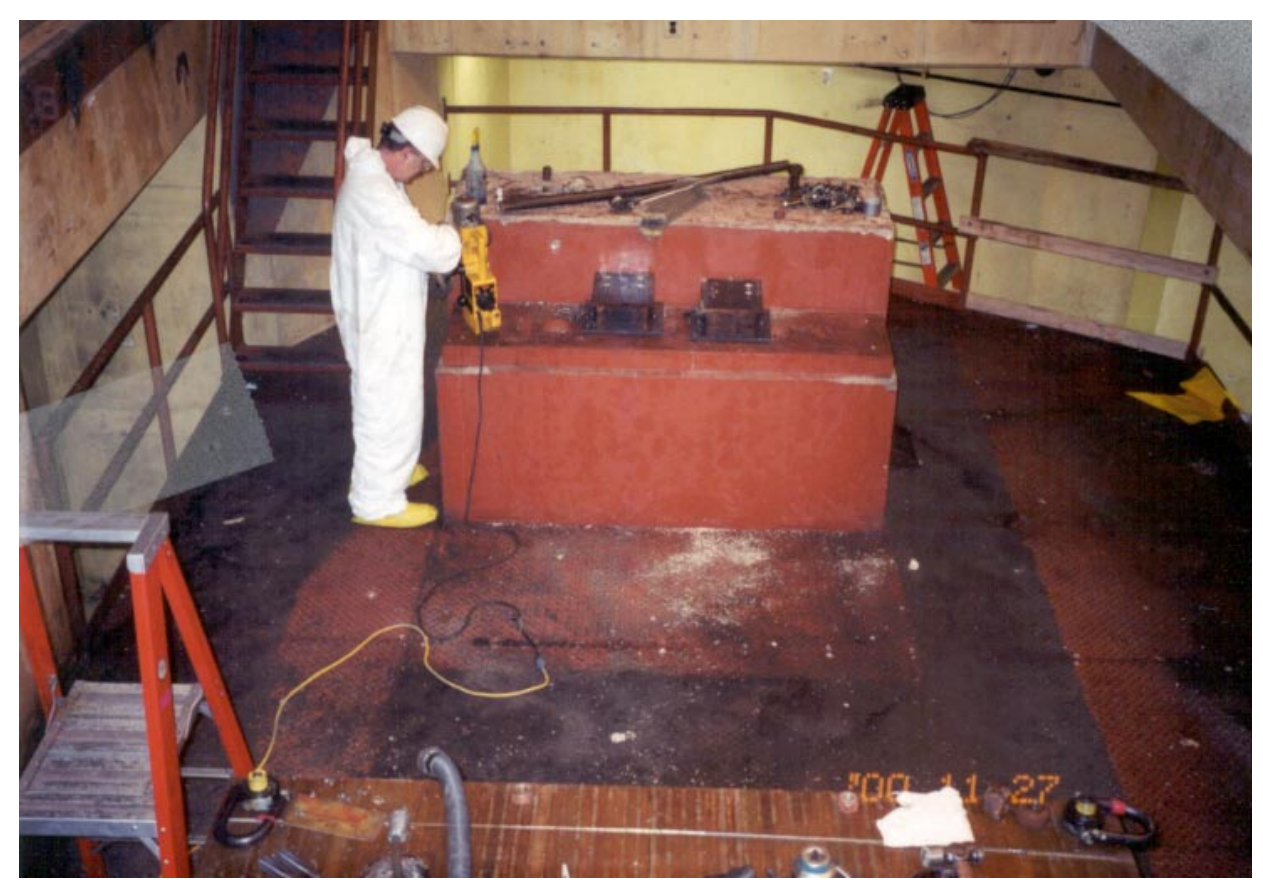

Figure 6.6 The Cyclotron Pedestal was Left in Place

(ANL Neg. 26241K, Frame 13)

\subsubsection{Hot Lab D\&D}

Three fume hoods and a sump for an adjacent unused laboratory were size reduced and packaged as LLRW. After size reduction of the junior cave, the hot lab was decontaminated. The fiberglass ceiling tiles and suspension system were removed and replaced with a new system. Building code violations for electrical conduit and the fire sprinkler system attached to the old suspension system were corrected at the same time. The asbestos floor tile and mastic were removed. The hot lab overhead crane cable and pendant were removed due to contamination, rendering the overhead crane non-operational. After this work and the $\mathrm{D} \& \mathrm{D}$ of the junior and senior caves, a final status survey was performed.

\subsubsection{Junior Cave}

The manipulator arms and ventilation system were removed and packaged as LLRW. The junior cave was disassembled and size reduced using an oxyacetylene torch. The three, 3 "-inch sections of leaded glass were packaged, without breakage, as LLRW, together with the cut pieces of the cave walls and ceiling. 


\subsubsection{Senior Cave}

The legacy waste was removed and packaged in a 55-gal drum, which was placed outside the D\&D area for later disposition. The manipulator arms, electrical panels, and all non-structural materials were removed and packaged as LLRW. The ventilation system was filled with a Hanford Disposal Site-approved foam to fix the high levels of contamination; then the ventilation system was removed, size reduced, and packaged as LLRW. The senior cave roof blocks were removed, decontaminated, and surveyed, including seating surfaces of both the blocks and the roof structure, prior to placing the blocks back in place.

\subsubsection{Vault Area}

After completing the removal of Cyclotron components, the entire vault was wiped down. A personnel lift provided access to upper walls and ceiling. All non-structural materials were removed. The window to the senior cave was drained, and the activated cover plate was removed and replaced with plywood. The sand was removed from the previously drained window to the electrical equipment room (A-119) so that the activated metal cover could be replaced. All penetrations were capped on the exterior of the vault. The damaged floor areas were filled with concrete, after completion of the final status survey and ORISE concurrence. The metal decking that covered conduit access troughs in the upper vault floor were removed and replaced with new diamond decking. A Unistrut ${ }^{\circledR}$ handrail was placed around the opening to the service floor, and a final status survey was performed. Figure 6.7 shows the service floor after D\&D activities were completed.

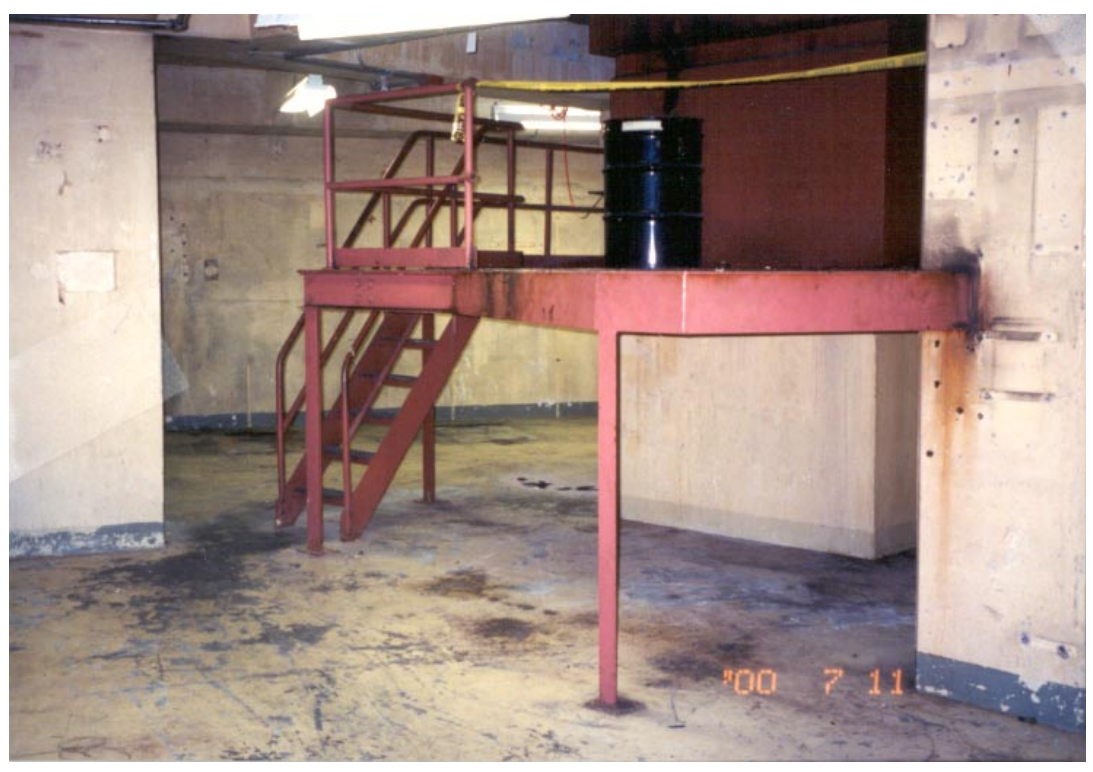

Figure 6.7 Cyclotron Facility Service Floor after Completion of D\&D Activities (ANL Neg. 26012K, Frame 10A) 


\subsubsection{Support Areas}

Areas A-119, A-133, A-011, A-033, and B-001 were wiped down. The final status survey area consisted of two meters up the vault wall and two meters out onto the floor parallel to the vault wall.

\subsubsection{Facility Asbestos Removal and Ceiling Tile Removal}

A State of Illinois-licensed asbestos contractor was mobilized in September 2000 to perform asbestos removal, specifically the floor tile and mastic in the hot lab and passageway from the vault to the hot lab, in radiological controlled areas of the Cyclotron. Fiberglass ceiling tiles in these areas were also removed to facilitate the final status survey.

\subsection{Final Status Survey}

\subsubsection{Decontaminate and Wipe Down Surfaces}

At the completion of D\&D activities, all surfaces were wiped down and vacuumed prior to performing a final status survey in an area.

\subsubsection{Perform Final Status Survey}

MOTA Corporation developed a Final Status Survey Plan that contained the methodology and requirements for the post-D\&D radiological survey. A separate Final Status Survey Procedure was written to implement that plan. These documents were developed specifically for the Cyclotron D\&D Project, and they were reviewed and approved by ANL-HP and ORISE.

MOTA's Final Status Survey documentation includes fourteen portfolios, each consisting of a Survey Package Control Form, General Instructions Form, Data Results from Smears, Survey Maps, and Survey Data Results. MOTA provided a detailed description of the methodology that was utilized in the Final Status Survey and a summary of the results in their Final Project Report.

ANL-E Health Physics provided health physics oversight, which included verification of MOTA's Final Status Survey results, by surveying at least $10 \%$ of the survey units.

All project records and documents, including the MOTA documents mentioned above, were archived at the completion of the project. 


\subsubsection{Final Survey Objectives}

The purpose of the final status survey was to demonstrate that the radiological conditions in the accessible areas of the Cyclotron facility satisfy the ANL-E unrestricted release guidelines presented in DOE Order 5400.5, Radiation Protection of the Public and the Environment.

\subsubsection{Project Objectives}

The specific objectives of the release survey included ensuring:

- Average surface contamination levels for each survey unit are within the authorized values. Small areas of residual activity (hot-spots) did not exceed three times the guideline value. The average activity within the $1 \mathrm{~m}^{2}$ area containing the hot spot is within the guideline. Reasonable efforts are made to clean up removable activity, and removable activity does not exceed the guideline value.

- Exposure rates in occupied locations are less then $7.5 \mu \mathrm{R} / \mathrm{hr}$ above background. Exposure levels are measured at $1 \mathrm{~m}$ from floor/lower wall surfaces and are averaged over floor areas, not to exceed $10 \mathrm{~m}^{2}$. The maximum exposure rate at $1 \mathrm{~m}$ does not exceed $10 \mu \mathrm{R} / \mathrm{hr}$ above background.

- The average and maximum dose rates associated with surface contamination resulting from beta-gamma emitters does not exceed $0.2 \mathrm{mrad}$ per hour at $1 \mathrm{~cm}$.

- Reasonable efforts are made to identify and remove all activated non-structural material.

- Detailed results of the final survey are included in the MOTA Corporation Final Survey Report.

\subsubsection{Unrestricted Release Criteria}

The release criteria applicable to the Cyclotron facility are based on DOE Order 5400.5 and ANL-E Health Physics Procedure HPP-610. On the basis of the combination of radiological contaminants present within the facility (see Table 6.2), the surface contamination guideline values for betagamma contamination were:

$83 \mathrm{~Bq}(5,000 \mathrm{dpm}) / 100 \mathrm{~cm}^{2}$, fixed plus removable contamination averaged over $1 \mathrm{~m}^{2}$; $250 \mathrm{~Bq}(15,000 \mathrm{dpm}) / 100 \mathrm{~cm}^{2}$, maximum fixed plus removable contamination; $17 \mathrm{~Bq}(1,000 \mathrm{dpm}) / 100 \mathrm{~cm}^{2}$, removable contamination. 
Surface contamination guidelines for transuranic alpha contamination were:

$1.67 \mathrm{~Bq}(100 \mathrm{dpm}) / 100 \mathrm{~cm}^{2}$, fixed and removable contamination averaged over $1 \mathrm{~m}^{2}$; $5 \mathrm{~Bq}(300 \mathrm{dpm}) / 100 \mathrm{~cm}^{2}$, maximum fixed plus removable contamination; $0.3 \mathrm{~Bq}(20 \mathrm{dpm}) / 100 \mathrm{~cm}^{2}$, removable contamination.

Exposure rates in occupied locations were $\leq 20 \mu \mathrm{R} / \mathrm{hr}$ above the background limit of DOE Order 5400.5. Exposure levels were measured at $1 \mathrm{~m}$ from floor/lower wall surfaces and averaged over floor areas (not exceeding $10 \mathrm{~m}^{2}$ ). Exposure rates at $1 \mathrm{~m}$ did not exceed $20 \mu \mathrm{R} / \mathrm{hr}$ above background at any location (i.e., upper walls and ceiling).

Table 6.2 Cyclotron Radiological Contaminants and Activation Products

\begin{tabular}{|c|l||}
\hline Radionuclide & \multicolumn{1}{c|}{ Location/Remarks } \\
\hline \hline${ }^{22} \mathrm{Na}^{*}$ & Vault/bucket of target holders \\
\hline${ }^{54} \mathrm{Mn} *$ & Vault/accelerator chamber, magnet yoke \\
\hline${ }^{55} \mathrm{Fe} *$ & Vault/magnet yoke and poles \\
\hline${ }^{60} \mathrm{Co}$ & Vault/magnet yoke and poles \\
\hline${ }^{63} \mathrm{Ni}^{*}$ & Vault/magnet yoke and poles \\
\hline${ }^{65} \mathrm{Zn} *$ & Vault/bucket of target holders \\
\hline${ }^{90} \mathrm{Sr}{ }^{90} \mathrm{Y}$ & Senior Cave/legacy waste \\
\hline${ }^{109} \mathrm{Cd}$ & Senior Cave/legacy waste \\
\hline${ }^{114} \mathrm{In}$ & Senior Cave/legacy waste \\
\hline${ }^{137} \mathrm{Cs}$ & Vault/buckets of target holders and beam line parts \\
\hline${ }^{226} \mathrm{Ra}$ & Senior Cave/legacy waste \\
\hline${ }^{228,230} \mathrm{Th}$ & Hot Lab and Senior/fume hoods and legacy waste \\
\hline${ }^{230,232,235,238} \mathrm{U}$ & Senior Cave/legacy waste \\
\hline${ }^{234} \mathrm{U}$ & Hot Lab/fume hoods and sump \\
\hline${ }^{239} \mathrm{Pu}$ & Senior Cave/roof contamination \\
\hline${ }^{242,243} \mathrm{Am}$ & Hot Lab and Senior Cave/fume hoods and legacy waste \\
\hline${ }^{244,245} \mathrm{Cm}$ & Senior Cave/roof contamination \\
\hline
\end{tabular}

*Denotes radionuclides that are difficult to detect with field instrumentation. The relative contribution of these radionuclides to the total activity present is expected to be low compared to easily detectable radionuclides. 


\subsubsection{Final Survey Approach}

Locations within the Cyclotron facility were divided into affected or unaffected survey units. These are defined as follows:

Affected Areas: Those areas that have potential radioactive contamination based on past operating history. They are also those areas and, where appropriate, the areas immediately surrounding or adjacent to them that have known radioactive contamination (based on past or preliminary radiological surveys) due to one or more of the following activities in an area: 1) the use or storage of radioactive materials; 2) spills or other unusual occurrence that could have resulted in the spread of contamination; or 3) the burial of radioactive material. Any area (room, system, etc.) that has been previously remediated will also be classified as an Affected Area. Areas that are expected to have, or formerly had, radioactive contamination existing at average levels in excess of $25 \%$ of the average total surface contamination, or greater than the Minimum Detectable Concentration (MDC) for the equipment used to perform the survey, whichever is larger, will be classified as Affected Areas.

Note: To allow a more concentrated survey effort in those areas most likely to be contaminated, Affected Areas within a room or building were further subdivided into Suspect Affected and Non-Suspect Affected Survey Units, as follows:

Suspect Affected Survey Units: The designation assigned to floor and wall surfaces below $2 \mathrm{~m}$ within an Affected Area. Also, the designation assigned to all additional surfaces if there is reason to believe that there was radioactive materials present, unless the criteria for a Non-Suspect Affected Survey Unit is met.

Non-Suspect Affected Survey Units: The designation assigned to upper wall, ceiling, and other horizontal and vertical surfaces above $2 \mathrm{~m}$ within an Affected Area, where it is not expected that radioactive materials exist at average levels in excess of $25 \%$ of the average total surface contamination guideline values, or the MDC for the equipment used to perform the survey, whichever is larger. This designation is based on engineering judgement, in consideration of operational history, characterization data, operational surveys performed in support of decommissioning, and routine surveillance.

Unaffected Areas: Those areas that have a low potential for radioactive contamination, based on knowledge of site history and previous survey information. Average measurements for average total surface contamination and for average concentrations of radionuclides are expected to be less than $25 \%$ of the applicable guideline value or less 
than the MDC for the equipment used to perform the survey, whichever is larger. Previous remediation precludes a survey area from being initially classified as unaffected.

Survey Unit: A division of survey area that has similar contamination and deposition patterns (e.g., floors, walls, horizontal surfaces). The maximum survey unit size is limited to approximately $100 \mathrm{~m}^{2}$ for affected areas and no survey unit included both affected and unaffected areas. Table 6.3 summarizes the survey area classifications and sizes.

Table 6.3 Cyclotron Survey Area Classifications and Description List

\begin{tabular}{|c|c|c|c|c|c|}
\hline \multicolumn{2}{|c|}{ Survey Area Description } & \multicolumn{3}{|c|}{ Survey Unit Classification } & \multirow{2}{*}{$\begin{array}{c}\text { Surface Area } \\
\left(\mathbf{m}^{2}\right)\end{array}$} \\
\hline $\begin{array}{c}\text { Area } \\
\text { ID }\end{array}$ & Survey Area Name & Floor & Lower Walls & $\begin{array}{c}\text { Upper } \\
\text { Walls/Ceiling } \\
\end{array}$ & \\
\hline 01 & C-001/101 & Class 1 & & & 1,445 \\
\hline 02 & C-001/101 & & Class 2 & & 2,425 \\
\hline 03 & C-001/101 & & & Class 2 & 7,375 \\
\hline 04 & B-126 & Class 1 & & & 2,750 \\
\hline 05 & B126 & & Class 1 & & 2,750 \\
\hline 06 & $\begin{array}{l}\text { A-011, A-033, } \\
\text { A-119, B-001 }\end{array}$ & Class 3 & Class 3 & Class 3 & 1,450 \\
\hline 07 & B-126 Senior Cave & Class 1 & Class 1 & Class 1 & 145 \\
\hline
\end{tabular}

\subsubsection{Potential Contaminants}

Based on knowledge of site operations and results from the characterization survey, the potential contaminants in the Cyclotron facility were as identified in Table 6.2. The final survey, including instrumentation selection, was designed to identify isotopes in quantities below the guideline values at the $95 \%$ confidence level.

A final status radiological survey was performed on the Cyclotron facility following the completion of D\&D work. The survey was performed in accordance with the Manual for Conducting Radiological Surveys in Support of License Termination (NUREG/CR-5849), and the approved Final Status Survey Plan. Griding for the final status survey started in October 2000, and the survey was completed in January 2001. 


\subsubsection{Instrumentation Selection}

Table 6.4 lists the instrumentation used by MOTA Corporation during the Final Status Survey. Calibration data sheets are included in the MOTA Final Survey Report.

Table 6.4 Instrumentation and Nominal Measurement Detection Sensitivities

\begin{tabular}{|c|c|c|c|c|c|}
\hline $\begin{array}{c}\text { Measurement } \\
\text { Type } \\
\end{array}$ & Detector & Meter & Background & $\begin{array}{c}4 \Pi \text { EFF. } \\
(\%) \\
\end{array}$ & $\begin{array}{c}\text { Detection } \\
\text { MDA } \\
\end{array}$ \\
\hline $\begin{array}{l}\text { Surface scans- } \\
\text { alpha }\end{array}$ & $\begin{array}{l}100 \mathrm{~cm}^{2} \\
\text { scintillation }\end{array}$ & Ludlum 177 & $1 \mathrm{cpm}$ & 20 & $300 \mathrm{dpm}$ \\
\hline $\begin{array}{l}\text { Surface scans- } \\
\text { alpha }\end{array}$ & $\begin{array}{l}100 \mathrm{~cm}^{2} \text { gas } \\
\text { proportional }\end{array}$ & Eberline E-600 & $3 \mathrm{cpm}$ & 30 & $300 \mathrm{dpm}$ \\
\hline $\begin{array}{l}\text { Surface scans- } \\
\text { beta }\end{array}$ & G-M pancake & Ludlum 177 & $40 \mathrm{cpm}$ & 12 & $1,600 \mathrm{dpm}$ \\
\hline $\begin{array}{l}\text { Surface scans- } \\
\text { beta }\end{array}$ & $\begin{array}{l}100 \mathrm{~cm}^{2} \text { gas } \\
\text { proportional }\end{array}$ & Eberline E-600 & $200 \mathrm{cpm}$ & 30 & $1,600 \mathrm{dpm}$ \\
\hline $\begin{array}{l}\text { Surface activity- } \\
\text { beta/gamma }\end{array}$ & $\begin{array}{l}600 \mathrm{~cm}^{2} \text { gas } \\
\text { proportional } \\
\text { floor monitor }\end{array}$ & Eberline E-600 & $1200 \mathrm{cpm}$ & 28 & $3,000 \mathrm{dpm}$ \\
\hline $\begin{array}{l}\text { Exposure rates } \\
\text { (a) } 1 \text { meter }\end{array}$ & $\begin{array}{l}1 " \times 2 " \mathrm{NaI} \\
\text { scintillation }\end{array}$ & Ludlum 19 & $5 \mu \mathrm{R} / \mathrm{hr}$ & N/A & $2 \mu \mathrm{R} / \mathrm{hr}$ \\
\hline $\begin{array}{l}\text { Gross } \\
\text { alpha/beta } \\
\text { on smears }\end{array}$ & $\begin{array}{l}\text { Gas proportional } \\
\text { or scintillation, } \\
\mathrm{t}_{\mathrm{s}}=1 \text { minute }\end{array}$ & $\begin{array}{l}\text { Protean } 9400 \\
\text { scaler or } \\
\text { Ludlum } 2929 \\
\text { dual-channel } \\
\text { scaler }\end{array}$ & $\begin{array}{c}0.3 \mathrm{cpm} \\
\text { alpha, } 48 \\
\text { cpm beta } \\
\mathrm{t}_{\mathrm{b}}=10 \text { min. }\end{array}$ & $\begin{array}{l}\text { 37-alpha } \\
\text { 28-beta }\end{array}$ & $\begin{array}{l}15 \mathrm{dpm} \text { alpha } \\
100 \mathrm{dpm} \text { beta }\end{array}$ \\
\hline
\end{tabular}

\section{6roject Closeout}

Project closeout activities included closing out all open RWP's and submitting final results to the appropriate ANL-E divisions. All final worker dose records were archived by ANL-HP. MOTA Corporation demobilized and removed all equipment off site. All waste was removed from the facility and transferred to PFS-WMO for final disposition.

The Cyclotron D\&D project report was prepared, summarizing the D\&D activities and the results. This final report documents the project's activities and concludes the Cyclotron D\&D Project. 


\subsection{INDEPENDENT VERIFICATION SURVEY (IVS)}

During February 2001, the Oak Ridge Institute for Science and Education performed an IVS of selected areas within the Cyclotron facility to verify the results of the contractor's final status survey.

\subsection{PROJECT COST}

The estimated total cost of the project was $\$ 3.9$ million.

\subsection{PROJECT EXPOSURE SUMMARY}

Over the project's 13-month duration, personnel received a total dose equivalent of 0.436 person-rem. Exposure dose equivalents to project personnel were estimated in the Cyclotron Project Plan issued in 1999. Table 9.1 provides a summary of the actual dose equivalent incurred during this project compared to the 1999-estimated dose equivalent.

Table 9.1 Project Total Radiation Dose Equivalent

\begin{tabular}{||l|c|c|c||}
\hline \multicolumn{1}{|c|}{ Description } & $\begin{array}{c}\text { Duration } \\
\text { (Months) }\end{array}$ & $\begin{array}{c}\text { Estimated Dose } \\
\text { Equivalent } \\
\text { (Person-Rem) }\end{array}$ & $\begin{array}{c}\text { Actual Dose } \\
\text { Equivalent } \\
\text { (Person-Rem) }\end{array}$ \\
\hline \hline Preparatory Activities & 0.5 & 0.008 & 0.001 \\
\hline Hot Lab D\&D, Including Caves & 5.0 & 1.486 & 0.411 \\
\hline Cyclotron Disassembly & 7.0 & 1.104 & 0.023 \\
\hline Project Closeout & 0.5 & 0.002 & 0.001 \\
\hline Total & $\mathbf{1 3 . 0}$ & $\mathbf{2 . 6 0 0}$ & $\mathbf{0 . 4 3 6}$ \\
\hline
\end{tabular}

\subsection{Occupational Exposure to Personnel}

All D\&D activities involving exposure to radioactive materials were performed using ALARA (As Low As Reasonably Achievable) philosophy. Only personnel who were essential to the performance of D\&D activities were exposed to radioactivity during D\&D operations. A project ALARA Committee was formed to review procedures and make recommendations to management where necessary for improving progress toward minimizing radiation exposure and radiological releases. The Committee evaluated items such as construction and design of the containment tent and decontamination/dismantling activities, as well as tested plans for exposure and waste minimization. 
The ALARA Committee met the requirements specified in Article 138 of the site-specific ANL-E Radiological Control Manual.

Engineering controls, including the construction of plastic sheeting-covered work-enclosures with HEPA-filtered air exhausts under negative pressure, were implemented where applicable. Protective clothing, including National Institute for Occupational Safety and Health (NIOSH)-approved respirators and breathing apparatus, were worn whenever workers were potentially exposed to airborne radioactivity. Tools and devices were remotely operated whenever possible. Personnel barriers around work zones were established, with contamination monitoring stations at points of egress. Work personnel ensured the open ends of pipes, tubes, and other components were sealed immediately upon disassembly. Educational films were used to assist personnel in training and understanding various activities involving radioactive materials.

All radiological work was performed under a Radiological Work Permit (RWP). The RWP is an administrative mechanism used to establish radiological control for intended work activities. The RWP informed workers of area radiological conditions and entry requirements, including pre-job briefing, training, and protective clothing. Postings were used to alert personnel to the presence of radiation and radioactive materials. Signs followed established color schemes and verbiage, and in areas of ongoing work activities, the dose rate and contamination level or range of each area was included on or in conjunction with each posting as applicable.

Area controls, such as rope and tape, indicated the boundaries of the work area and followed established color schemes and criteria. To prevent the spread of radioactive contaminants off-site, all personnel, vehicles, tools, and other equipment were surveyed for contamination prior to leaving the work area.

\section{$9.2 \quad$ Total Dose}

The original estimated dose to Cyclotron D\&D project personnel was 2.6 person-rem over the lifetime of the project. The actual dose was 0.436 person-rem.

\subsection{WASTE VOLUME}

\subsection{Waste Types}

D\&D field work began in January 2000, with waste generation occurring until project closeout in February 2001. Cobalt-60 was the predominant radionuclide of concern for the Cyclotron assembly. Due to activation concerns, all items in the controlled area that were present during Cyclotron operations were disposed of as radioactive waste or recycled (on-site only) even if there was no detectable activity. 
All waste materials generated during this project were classified as either LLRW, mixed waste, or were recycled on-site only in accordance with the criteria contained in "DOE Guidelines for Residual Radioactivity at Formerly Utilized Sites Remedial Action Program and Remote Surplus Facilities Management Program Sites." Radioactively contaminated waste was further classified according to its composition and the level of its radioactivity. Liquid radioactive waste was transferred directly to PFS-WMO in approved containers and converted to a solid form using existing ANL-E waste processing facilities.

Mixed waste was transferred to PFS-WMO for final disposition. Low-level radioactive waste was packaged at the Cyclotron facility and transferred to PFS-WMO.

A total of approximately $220,726 \mathrm{lb}$ of steel from the segmented Cyclotron yoke was recycled on-site as shielding material for the Physics Division ATLAS accelerator.

\subsubsection{Waste Generation}

The Cyclotron D\&D Project generated approximately $6,971 \mathrm{ft}^{3}$ of LLRW and $115 \mathrm{ft}^{3}$ of mixed waste requiring off-site disposal. The waste included materials and equipment that could not be decontaminated, including Cyclotron components, support equipment, legacy waste, and nonstructural building materials comprised primarily of metal. Neither high-level nor TRU waste was generated during this project.

Generated waste material was packaged and shipped using B-12 half-bins ( $\left.44 \mathrm{ft}^{3}\right)$ for thick metal components and B-25 $\left(101 \mathrm{ft}^{3}\right)$ full bins for other materials. Table 10.1 provides a summary of the waste packaged:

Table 10.1 Low Level Radioactive and Mixed Waste Packaged

\begin{tabular}{||c|c|c|c|c|c||}
\hline Contents & $\begin{array}{c}\text { Number of } \\
\text { Packages }\end{array}$ & $\begin{array}{c}\text { Volume* } \\
\left.\mathbf{( f t}^{\mathbf{3}}\right)\end{array}$ & $\begin{array}{c}\text { Weight* } \\
(\mathbf{l b})\end{array}$ & $\begin{array}{c}\text { Activity } \\
(\mathbf{C i})\end{array}$ & $\begin{array}{c}\text { Maximum } \\
\text { Dose Rate }\end{array}$ \\
\hline \hline LLRW & 74 & 6,971 & 377,159 & $5.1 \times 10^{-2}$ & 50.0 \\
\hline Mixed Waste & 6 & 115 & 12,811 & $2.9 \times 10^{-5}$ & 0.20 \\
\hline Total & $\mathbf{8 0}$ & $\mathbf{7 , 0 8 6}$ & $\mathbf{3 8 9 , 9 7 0}$ & $\mathbf{5 . 1 \times \mathbf { 1 0 } ^ { - 2 }}$ & \\
\hline
\end{tabular}

*Including liners, when applicable

The weights for generated LLRW and mixed waste in individual containers ranged from 2 to $19,738 \mathrm{lb}$, with a total generated waste weight of $933,806 \mathrm{lb}$ and total generated waste volume of 
$8,408 \mathrm{ft}^{3}$. Total activity of the individual packages ranged from $9.2 \times 10^{-7}$ to $1.1 \times 10^{2} \mathrm{Ci}$, with a total activity for all generated waste of $1.1 \times 10^{2}$. The dose rates from the individual packages ranged from $<0.1$ to $50 \mathrm{mR} / \mathrm{hr}$ at $1 \mathrm{~m}$.

\subsubsection{Special Waste}

There were three hazardous material waste streams generated during the D\&D of the Cyclotron facility. They were PCB's, asbestos, and contaminated lead.

Approximately 2,574 $\mathrm{ft}^{3}$ of asbestos, weighing $642 \mathrm{lb}$, was removed from the facility. All asbestoscontaining material was loaded, sealed, and transferred to PFS-WMO for final disposition.

Additionally, 11,697 lb of lead was removed from the Cyclotron facility. Survey efforts resulted in release for on-site recycling of 2,500 lb. The remaining $9,197 \mathrm{lb}$ of potentially activated lead was disposed of as mixed waste in 55 gallon drums and B-12 bins with a total volume of $115 \mathrm{ft}^{3}$. These drums ranged in weight from 88 to $990 \mathrm{lb}$, with a total weight of $12,811 \mathrm{lb}$, including liners. The activity of the individual drums ranged from $10 \times 10^{-6}$ to $2.1 \times 10^{-5} \mathrm{Ci}$, with a total activity of $3 \times 10^{-5} \mathrm{Ci}$. The dose rates emitted from the packages ranged from $<0.02$ to $50 \mathrm{mR} / \mathrm{hr}$.

Waste packaging operations complied with the ANL Waste Handling Procedures Manual, U.S. Department of Transportation (49CFR) regulations, and the requirements of the designated disposal site. MOTA Corporation supplied B-25 and B-12 metal boxes, and 55-gal drums for LLRW and mixed waste which were loaded, sealed, and transferred to PFS-WMO for final disposition.

PCB contamination was found in some electrical equipment. The equipment was disposed of as mixed waste. Some small quantities of liquid hazardous waste (oil and grease) were packaged into appropriate containers and transferred to PFS-WMO for final disposition.

Some material was recycled for on-site use. Steel blocks were transferred to the Physics Division ATLAS accelerator for use as shielding material. Lead was transferred to the "Lead Bank" for on-site reuse.

\subsection{WASTE PACKAGING}

Packaging of radioactive waste generated by the Cyclotron D\&D Project conformed with Department of Transportation (DOT) regulations and the requirements of the receiving waste disposal site. Standard 55 gal drums, and B-25 and B-12 bins were filled with LLRW, sealed, and transported off-site or placed into on-site storage. Only B-12 bins were used for mixed waste. Steel blocks from the Cyclotron yoke that were not recycled, were shipped without packaging. 
Liquid radioactive waste generated during decontamination operations was processed by PFS-WMO into a solid by evaporation or other means after neutralization. Total accumulation of liquid volumes was approximately 350 gallons over the term of the project.

\subsection{Waste Transport}

Packaged radioactive waste from the project was transported to the DOE radioactive waste disposal site by "Exclusive Use" tractor-trailer trucks. Cyclotron waste was sometimes combined with other low-level radioactive waste generated from other ANL-E operations and sent to the DOE sites for disposal. Special transport vehicles were used to ship radioactive items that could not be transported routinely due to size, weight, radioactivity, or a combination of characteristics. All radioactive waste shipments met DOT and DOE regulations for transporting such materials.

\subsection{FINAL FACILITY CONDITION}

The radioactive release criteria established for the Cyclotron D\&D Project are based on the requirements outlined in DOE Order 5400.5, "Radiation Protection of the Public and the Environment" and ANL-E. These limits are as follows:

For beta-gamma emitters (e.g., $\left.\mathrm{Cs}^{137}\right)$ :

$83 \mathrm{~Bq}(5000 \mathrm{dpm}) / 100 \mathrm{~cm}^{2}$, average (over $1 \mathrm{~m}^{2}$ ) fixed plus removable contamination, $17 \mathrm{~Bq}(1000 \mathrm{dpm}) / 100 \mathrm{~cm}^{2}$, removable contamination, and

$250 \mathrm{~Bq}(15,000 \mathrm{dpm}) / 100 \mathrm{~cm}^{2}$, maximum fixed plus removable contamination.

For transuranic contamination (e.g., $\left.A m^{241}\right)$ :

$1.67 \mathrm{~Bq}(100 \mathrm{dpm}) / 100 \mathrm{~cm}^{2}$, average (over $1 \mathrm{~m}^{2}$ ) fixed plus removable contamination, $0.3 \mathrm{~Bq}(20 \mathrm{dpm}) / 100 \mathrm{~cm}^{2}$, removable contamination, and

$5 \mathrm{~Bq}(300 \mathrm{dpm}) / 100 \mathrm{~cm}^{2}$, maximum fixed plus removable contamination.

All accessible surface areas within the Cyclotron facility were decontaminated to below these levels. Additionally, exposure rates in both occupied locations and at $1 \mathrm{~m}$ from the surface were measured at no more than $20 \mu \mathrm{R} / \mathrm{h}$ above background, and met DOE Order 5400.5 criteria. All areas in the Cyclotron facility containing residual radioactivity above these release criteria were made inaccessible. Specific spots (e.g., in the hot lab area) identified by ORISE as needed further decontamination were made inaccessible by means of capping with metal covers and posting the covers with a sign informing personnel of the radiological conditions below the cover. Based on these results and lack of additional hazardous materials at the site, the Cyclotron facility was released

for unrestricted reuse. Currently, standard safety training and building orientation are required to 
Cyclotron D\&D Project

Final Report

Page 38 of 43

enter the facility unescorted; but, RWP's, exposure monitoring, and additional controls are no longer in effect.

\subsection{CONCLUSIONS, RECOMMENDATIONS, AND LESSONS LEARNED}

The completion of the Cyclotron D\&D Project signaled the release of the Cyclotron vault and surrounding area from DOE-Environmental Management control. The Cyclotron facility, at this time, has no identified future use.

\subsection{General Problems Encountered and Lessons Learned}

The decontamination and decommissioning of an accelerator facility poses unique challenges. However, solutions to those problems may be applicable to situations encountered during other similar D\&D projects. The following section describes problems encountered, remediation of these problems, and lessons learned.

\subsubsection{General Problems Encountered}

The Characterization Report provided inaccurate and insufficient information that resulted in unforeseen radiological problems. An underlying cause of the radon gas incident was inattention to detail during the characterization process regarding radionuclide type and exact Curie content. Project safety, cost, and schedule were adversely affected due to the problems that resulted from the incident. Extensive involvement in the characterization process by TD D\&D personnel would ensure that accurate, detailed identification of radiological hazards present at the project are described in the Characterization Report.

\subsubsection{Problem Remediation/Resolution}

The junior cave provided a unique engineering problem during dismantling. The junior cave comprised 3-in-thick steel walls, with two sides $48 \mathrm{ft}^{2}$ each and two sides $12 \mathrm{ft}^{2}$ each. The hot lab did not have an existing crane that could be utilized. The contractor erected an A-frame crane that was load tested in place and met required certifications. The cave walls were individually braced, then lowered to the floor one at a time. The walls were size reduced using an oxyacetylene torch and packaged as LLRW. The junior cave was safely dismantled by the subcontractor using sound engineering techniques.

\subsubsection{General Lessons Learned}

Accurate and detailed entries on $R W P$ sign-in sheets provided valuable information for dose assessment and analysis. During the investigation of the unplanned release of radon gas, it was noted that all workers involved directly or indirectly did adhere to the requirement of signing in and 
out on the correct RWP. Consistent, methodical radiological work practices are an integral part of a successful $D \& D$ project. The documented time was a valuable tool during the investigation process in estimating worker exposures to the radon gas.

Disregard assumptions and interpretations of radiological characterization reports. During the investigation of the unplanned release of radon gas, it was determined that the actual amounts of radioactive material labeled on containers and described in the Characterization Report were incorrect. Prudent analysis of the Characterization Report and preparation of a "worst case scenario" are important when handling and packaging potentially unknown radiological waste.

\subsection{Noteworthy Practices}

The Cyclotron Project personnel maintained a pro-active approach to safety throughout the project and completed the project without a recordable or lost time incident.

Lift plans were incorporated at the inception of the project. Prior to rigging and hoisting operations, workers formulated lift plans that provided guidance in proper use and selection of equipment. Project Management and Safety Engineering staff approved these Lift Plans. The Cyclotron D\&D Project was completed without any hoisting and rigging incidents.

Used Personal Protective Equipment (PPE) and paper waste was used as filler in waste packaging. An abundance of waste metal resulted in void spaces in the waste containers. PPE, consisting of Tyvek ${ }^{\circledR}$ suits, plastic shoe covers, and surgical gloves, were easily compactable. The contractor maximized space in LLRW bins by filling in void spaces with PPE, reducing the need to use clean void as filler.

Use of existing equipment provided engineering and material cost savings. Cyclotron block segments were transported outside the building using an existing cart. The cart was originally used for movement of heavy equipment during cyclotron operation activities. Use of this cart provided a safe method for transporting the block segments as well as eliminating the need to purchase a new transport system. 
Cyclotron D\&D Project

Final Report

Page 40 of 43

Page Left Blank 


\subsection{ACRONYM AND ABBREVIATION LISTING}

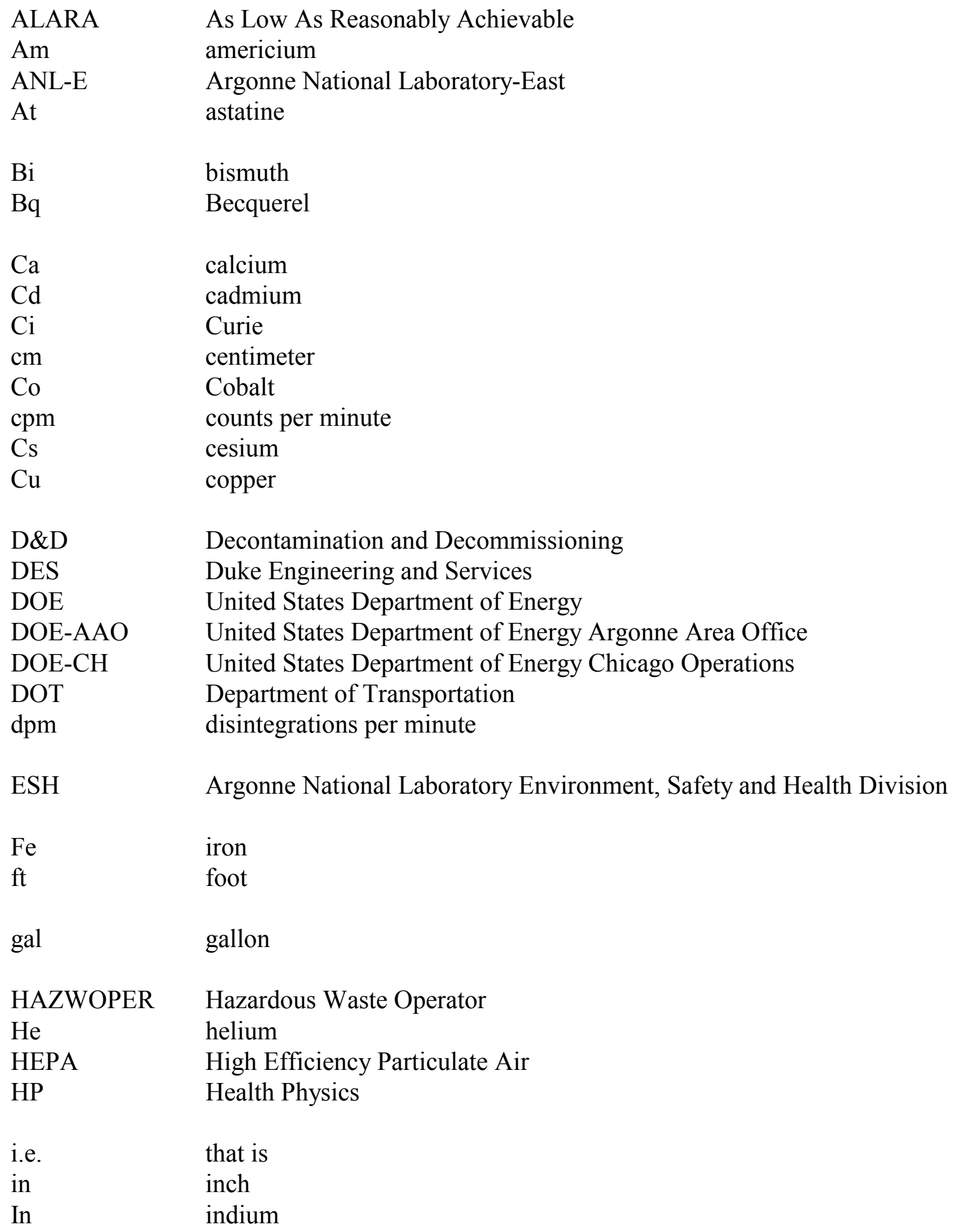




\begin{tabular}{|c|c|}
\hline IVS & Independent Verification Survey \\
\hline $1 \mathrm{~b}$ & pound \\
\hline LINAC & Argonne National Laboratory Chemistry Division's Linear Accelerator \\
\hline LLRW & low level radioactive waste \\
\hline $\mathrm{m}$ & meter \\
\hline MDC & Minimum Detectable Concentration \\
\hline $\mathrm{MeV}$ & million electron volts \\
\hline $\mathrm{Mn}$ & manganese \\
\hline mrem & millirem \\
\hline $\mathrm{Na}$ & sodium \\
\hline $\mathrm{Ni}$ & nickel \\
\hline NMG & Nuclear Medicine Group \\
\hline NIOSH & National Institute for Occupational Safety and Health \\
\hline OSHA & Occupational Safety and Health Administration \\
\hline ORISE & Oak Ridge Institute for Science and Education \\
\hline PCB & polychlorinated biphenyl \\
\hline PFS & Argonne National Laboratory Plant Facilities and Services Division \\
\hline PPE & Personal Protective Equipment \\
\hline $\mathrm{Pu}$ & plutonium \\
\hline QA & quality assurance \\
\hline QAR & Quality Assurance Representative \\
\hline $\mathrm{Ra}$ & radium \\
\hline rem & Roentgen equivalent man \\
\hline RWP & Radiological Work Permit \\
\hline Sc & scandium \\
\hline $\mathrm{Sr}$ & strontium \\
\hline TD & Argonne National Laboratory Technology Development Division \\
\hline Th & thorium \\
\hline $\mathrm{U}$ & uranium \\
\hline $\mathrm{V}$ & volt \\
\hline
\end{tabular}


Cyclotron D\&D Project

Final Report

Page 43 of 43

WMO Argonne National Laboratory Plant Facilities and Services Waste Management Operations

Y yttrium

Zn $\quad$ zinc 